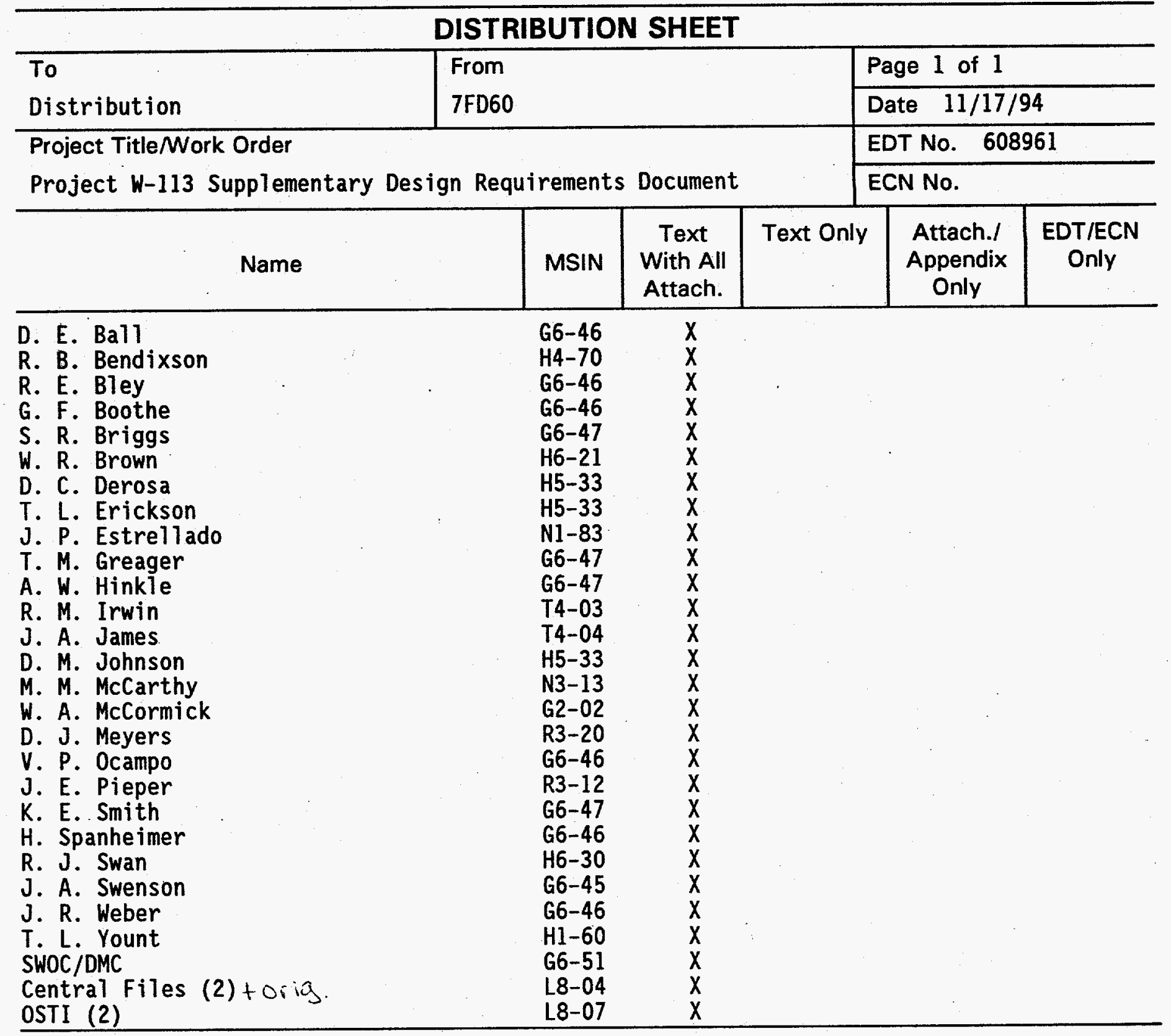




\section{DISCLAIMER}

Portions of this document may be illegible in electronic image products. Images are produced from the best available original document. 


\section{To: (Receiving Organization) \\ Distribution}

5. Proj./Prog./Dept./Div.:

W-113

8. Originator Remarks:

For release. Review comments from EDT 602965 have been incorporated.

11. Receiver Remarks:
3. From: (originating Organization) 7FD60

6. Cog. Engr.:

V. P. Ocampo
4. Related EDT Mo.:

602965

7. Purchase Order No.:

$N / A$

9. Equip./Component Mo.:

$N / A$

10. System/Bldg./Facility:

$$
\text { N/A }
$$

12. Major Assm. Dwg. No.:

N/A

13. Permit/Permit Application No.: N/A

14. Required Response Date:

$N / A$

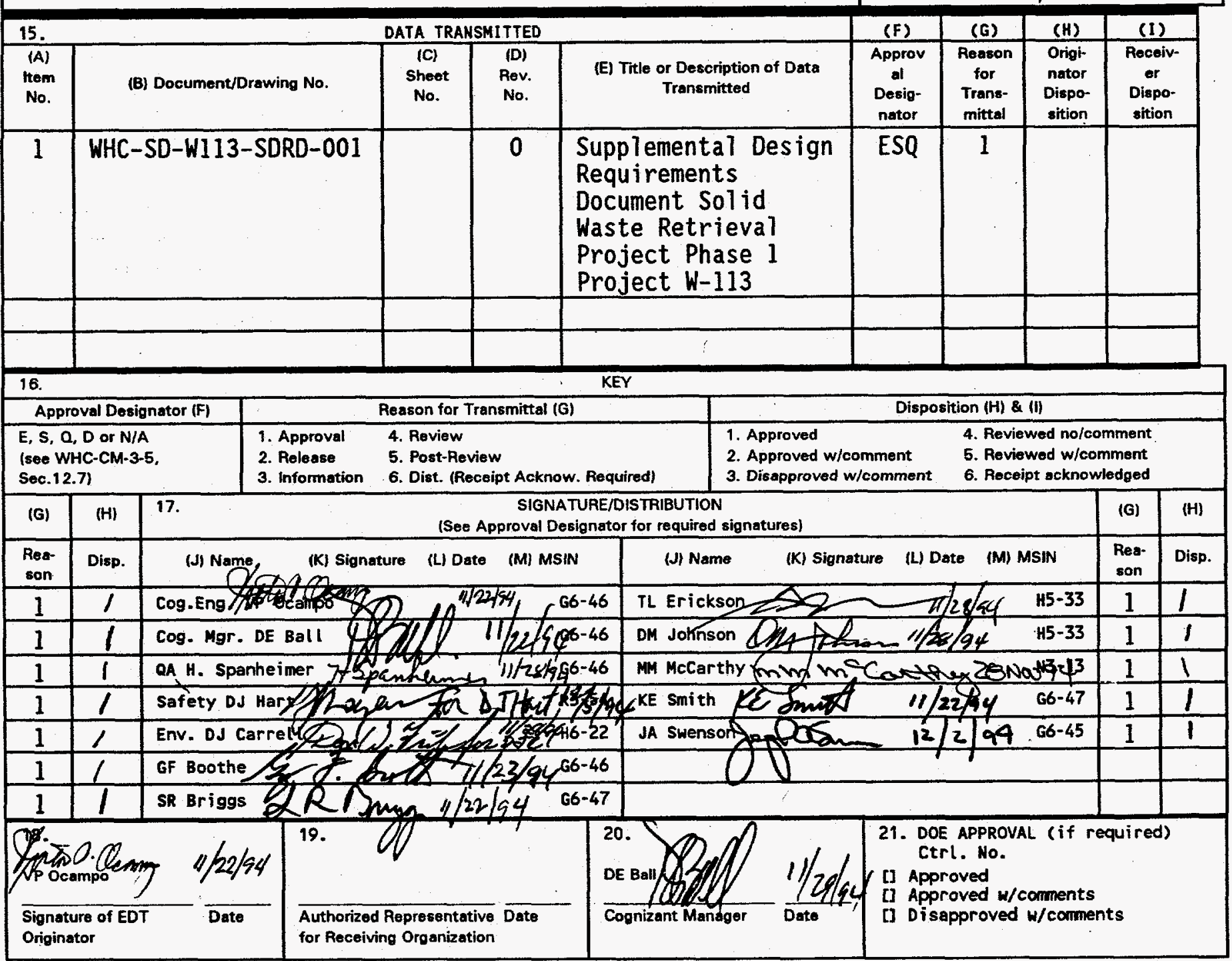

BD-7400-172-2 (04/94) GEF097 


\section{RELEASE AUTHORIZATION}

Document Number: WHC-SD-W113-SDRD-001, REV. 0

Document Title: $\quad$ SupplementaTyDesign Requirements Document Sol id Waste Retreival Project Phase 1 Project W-113

Release Date: $\quad 12 / 8 / 94$

This document was reviewed following the procedures described in WHC-CM-3-4 and is:

APPROVED FOR PUBLIC RELEASE

WHC Information Release Administration Specialist:

Chrie 3ritlézhano

C. Willingham

$12 / 8 / 94$ 


\begin{tabular}{|c|c|c|}
\hline $\begin{array}{l}\text { 2. Title } \\
\text { Supplementary Design Requirements Document Sol id } \\
\text { Waste Retrieval Project Phase } 1 \text { Project } W-113\end{array}$ & $\begin{array}{l}\text { 3. Number } \\
\text { WHC-SD-W113-SDRD-001 }\end{array}$ & $\begin{array}{c}\text { 4. Rev No. } \\
0\end{array}$ \\
\hline $\begin{array}{l}\text { 5. Key words } \\
\text { Project } W-113 \text {, SDRD }\end{array}$ & $\begin{array}{l}\text { 6. Author } \\
\text { Mamg: V. P. Ocampo } \\
\text { Organization/Charge code } 7\end{array}$ & $D 60 / A 85 A 2$ \\
\hline
\end{tabular}

\section{Abstract}

This document provides additional and supplemental information to the WHC-SD-W113-FDC-001, Project W-113. It provides additional requirements for the design and summarizes Westinghouse Hanford Company key design guidance and establishes the technical baseline agreements to be used for definitive design of the Project $W-113$ facilities.

\section{APPROVED FOR PUBLIC RELEABE $\omega_{1 / 2.8^{-94}}$}

8. UURPOSE AND USE OF DOCUMENT - This document was prepared for use whin in the U.S. Department of Energy and its contractors. It is to be used only to perform, direct, or intearate work under U.S. Departmoat of Energy contracts. This doedment is not approved for publ ic release-until reviewed.

PATENT STATUS - This documents bPy, since it is transmitted in advance of patent clearance $1 s$ made-available in confidence solely for use in performapes of work undor contracts with the U.S. Department of Energy. This document is not ta be publ ished nor its contents otherwise disseminated or used for purposecether than specified above before patent approval for such release or doen has been secured, upon request, from the Patent Counsel, U.S. Department of Energy Field office, Richland, WA.

DISCLAIMER - This report was prepared as an account of work sponsored by an agency of the United States Government. Neither the United States Government nor any agency thereof, nor any of their employees, nor any of their contractors, subcontractors or their employees, makes any warranty, express or implied, or assumes any legal liability or responsibility for the accuracy, completeness, or any third party's use or the results of such use of any information, apparatus, product, or process disclosed, or represents that its use would not infringe privately owned rights. Reference herein to any specific commercial product, process, or service by trade name, trademark, manufacturer, or otherwise, does not necessarily constitute or imply its endorsement, recormendation, or favoring by the United States Government or any agency thereof or its contractors or subcontractors. The views and opinions of authors expressed herein do not necessarily state or reflect those of the United States Goverrment or any agency thereof.

9. Impact Level ESQ

10. RELEASE STAMP

OFFICIAL PELEASE

BY WHC

DATE DEC 121994

35 station 21 
WHC-SD-W113-SDRD-001 REV 0

SUPPLEMENTARY DESIGN REQUIREMENTS DOCUMENT SOLID WASTE RETRIEVAL PROJECT

PHASE 1 PROJECT W-113

CONTRIBUTING AUTHORS

G. F. Boothe

J. A. Hubbard

V. P. Ocampo

J. E. Pieper

K. E. Smith

J. R. Weber

Westinghouse Hanford Company

Richland, Washington 


\title{
SUPPLEMENTAL DESIGN REQUIREMENTS DOCUMENT \\ ENHANCED RADIOACTIVE AND MIXED WASTE \\ STORAGE PHASE V PROJECT W-113
}

\author{
Issued By: \\ Westinghouse Hanford Company \\ November 1994 \\ for the \\ United States Department of Energy, Richland Operations Office \\ Richland, Washington
}

Prepared by:
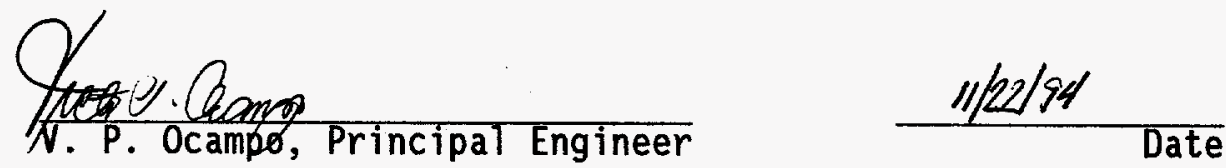

Contractor Approval:

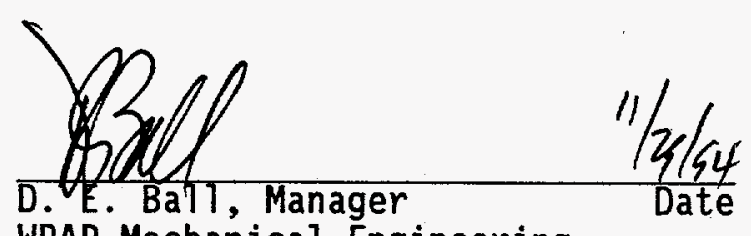

WRAP Mechanical Engineering

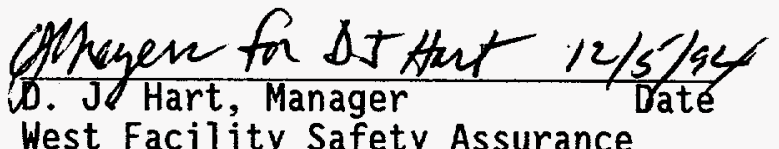

West Facility Safety Assurance

m.m.micarthe $28 \mathrm{NaN} 94$ M. M. McCarthy, Manager Date Restoration and Upgrade Programs

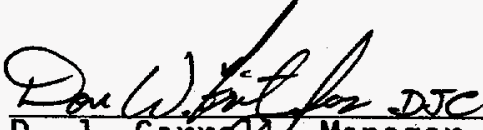

D. J. Carred, Manager

Environmental Policy

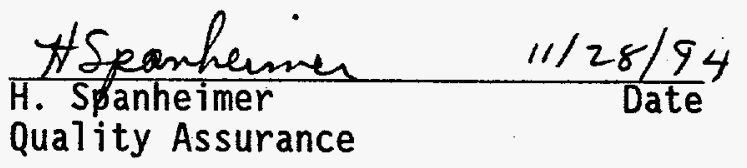

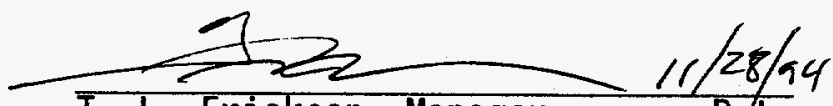

T. L. Erickson, Manager Restoration Projects

Date

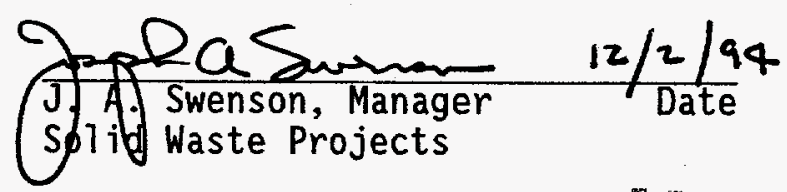

MASTER 


\title{
ACRONYMS, ABBREVIATIONS, AND INITIALIZATIONS
}

$\begin{array}{ll}\text { AAS } & \text { Alarm and Annunciation System } \\ \text { ACES } & \text { Access Control Entry System } \\ \text { A/E } & \text { Architect/Engineer } \\ \text { CAM } & \text { continuous air monitor } \\ \text { CH } & \text { contact-handled } \\ \text { CVS } & \text { Container Venting System } \\ \text { DBA } & \text { Design Basis Accident } \\ \text { DMS } & \text { Data Management System } \\ \text { DOE } & \text { U.S. Department of Energy } \\ \text { FDC } & \text { Functional Design Criteria } \\ \text { HEPA } & \text { high efficiency particulate air } \\ \text { HGSS } & \text { Head Gas Sampling Subsystem } \\ \text { HLAN } & \text { Hanford Local Area Network } \\ \text { HPT } & \text { Health Physics Technician } \\ \text { I\&C } & \text { Instrumentation and Control } \\ \text { LAN } & \text { Local Area Network } \\ \text { LLW } & \text { low-level waste } \\ \text { MFPL } & \text { maximum possible fire loss } \\ \text { MMI } & \text { man-machine interface } \\ \text { NDA } & \text { nondestructive assay } \\ \text { NDE } & \text { nondestructive examination } \\ \text { NEC } & \text { National Electrical Code } \\ \text { NEMA } & \text { National Electrical Manufacturers Association } \\ \text { NFPA } & \text { National Fire Protection Association } \\ \text { OSHA } & \text { Occupational Safety and Health Administration } \\ \text { PAN } & \text { passive active neutron } \\ \text { PCS } & \text { Plant Control System } \\ \text { PSAR } & \text { Preliminary Safety Analysis Report } \\ \text { RCA } & \text { Radiologically Controlled Area } \\ \text { RCRA } & \text { Resource Conservation and Recovery Act } \\ \text { SARP } & \text { Safety Analysis Report Packaging } \\ \text { SDRD } & \text { Supplemental Design Requirements Document } \\ \text { SWOC } & \text { Solid Waste Operations Complex } \\ \text { TRU } & \text { transuranic } \\ \text { VOC } & \text { volatile organic compounds } \\ \text { WAC } & \text { Washington Administrative Code } \\ \text { WHC } & \text { Westinghouse Hanford Company } \\ \text { WRAP } & \text { Waste Receiving and Processing } \\ & \end{array}$

\section{DISCLAIMER}

\begin{abstract}
This report was prepared as an account of work sponsored by an agency of the United States Government. Neither the United States Government nor any agency thereof, nor any of their employees, makes any warranty, express or implied, or assumes any legal liability or responsibility for the accuracy, completeness, or usefulness of any information, apparatus, product, or process disclosed, or represents that its use would not infringe privately owned rights. Reference herein to any specific commercial product, process, or service by trade name, trademark, manufacturer, or otherwise does not necessarily constitute or imply its endorsement, recommendation, or favoring by the United States Government or any agency thereof. The views and opinions of authors expressed herein do not necessarily state or reflect those of the United States Government or any agency thereof.
\end{abstract}




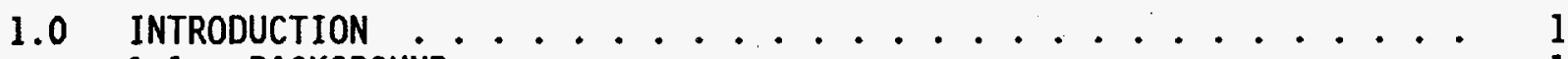

1.1 BACKGROUND $\ldots \ldots \ldots \ldots \ldots \ldots$

1.2 SCOPE $\ldots \ldots \ldots \ldots \ldots \ldots \ldots \ldots \ldots \ldots \ldots$

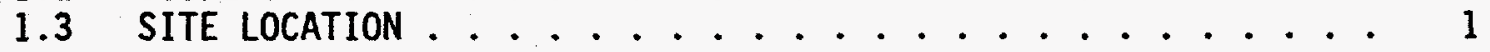

2.0 PROJECT CRITERIA . . . . . . . . . . . . . 6

2.1 PROJECT DESIGN BASES . . . . . . . . . . . . . 6

2.1 .1 Functional Requirements $\ldots \ldots 6$

2.1.2 Waste Feed Streams and Throughput Requirements . . . 6

2.1 .3 Source Terms . . . . . . . . . . . . 13

3.0 PROCESS CRITERIA $\ldots \ldots \ldots 13$

3.1 RETRIEVAL AND MATERIAL HANDLING . . ........ 13

3.1 .1 Remove Containers ............. 13

3.1 .2 Process Newly Generated Waste . . . . . . . 16

3.2 HANDLE CONTAINERS .................... 16

3.2.1 Equipment/Operational Requirements ........ 16

3.2 .2 overpack Containers ............. 17

3.2 .3 Apply Barcode Label ............. 18

3.2 .4 Shielding ............... 18

3.2 .5 Contamination Control ........... 18

3.3 CHARACTERIZE WASTE ....................... 19

3.3 .1 NDA Drums . . . . . . . . . . . . . 19

3.3 .2 Weigh Drums .............. . . 19

3.3.3 Vent Drums/Head Gas Sampling ........... 19

3.3 .4 NDE Drums ............... . . 20

3.4 STAGE CONTAINERS FOR ON-SITE TRANSFER ........ 20

3.5 PLANT CONTROL SYSTEM . . . . . . . . . . . 20

3.6 DATA MANAGEMENT SYSTEM ................... 20

3.7 RADIATION AND AIR MONITORING ............. 21

4.0 FACILITY CRITERIA . . . . . . . . . . . . . . . 22

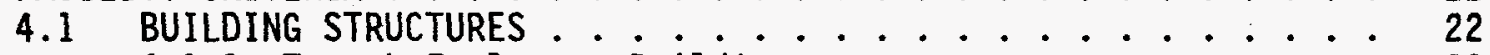

4.1.1 Trench Enclosure Building ........... 22

4.1.2 Retrieval Operations Building .......... 22

4.1.3 General Office Building ............. 23

4.1.4 Retrieval Staff Change Building . . . . . . . 24

4.2 EQUIPMENT DESIGN REQUIREMENTS ............ 25

4.2 .1 Ultrasonic Testing Equipment . . . . . ... 25

4.2 .2 Soil Vacuum Equipment ............. 26

4.2 .3 NDE Equipment ............... 26

4.2 .4 NDA Equipment . . . . . . . . . . . 27

4.2 .5 CVS Equipment .............. . . 30

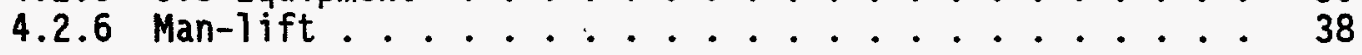

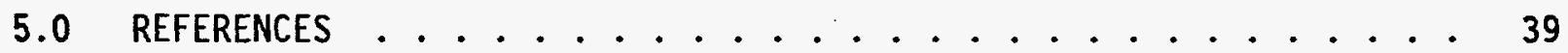




\section{SUPPLEMENTAL DESIGN REQUIREMENTS DOCUMENT \\ SOLID WASTE RETRIEVAL PROJECT \\ PHASE 1 PROJECT W-113}

\subsection{INTRODUCTION}

\subsection{BACKGROUND}

This Supplemental Design Requirements Document (SDRD) is used to communicate Project $W-113$ specific plant design information from Westinghouse Hanford Company (WHC) to the United States Department of Energy (DOE) and the cognizant Architect Engineer (A/E). The SDRD is prepared after the completion of the project Conceptual Design report (CDR) and prior to the initiation of definitive design. Information in the SDRD serves two purposes: to convey design requirements that are too detailed for inclusion in the Functional Design Criteria (FDC) report and to serve as a means of change control for design commitments in the Title I and Title II design.

The Solid Waste Retrieval Project ( $W-113)$ SDRD has been restructured from the equipment based outline used in previous SDRDs to a functional systems outline. This was done to facilitate identification of deficiencies. in the information provided in the initial draft SDRD and aid design confirmation. The format and content of this SDRD adhere as closely as practicable to the requirements of WHC-CM-6-1, Standard Engineering Practices for Functional Design Criteria.

\subsection{SCOPE}

The function of Project $W-113$ in the Hanford mission as shown in the Figure 1, Functional Analysis Diagrams, is the Phase 1 retrieval of CH-TRU waste in Trench 04 of the $218-W-4 C$ burial ground. located in the 200 West area.

The overall systems engineering steps used to reach construction and operation of Project $W-113$ are depicted in Figure 1 . The Project $W-113$ SDRD focuses on the requirements to address the functional analys is provided in Figure 1. This information is provided in Sections 2 through 4 of this SDRD.

\subsection{SITE LOCATION}

Project $W-113$ will be located in the 200W Area at the burial ground 218W-4C, Trench 4C-04. 
Fig. 1 Project W-113 Functional Analysis

Sht. 1 of 4

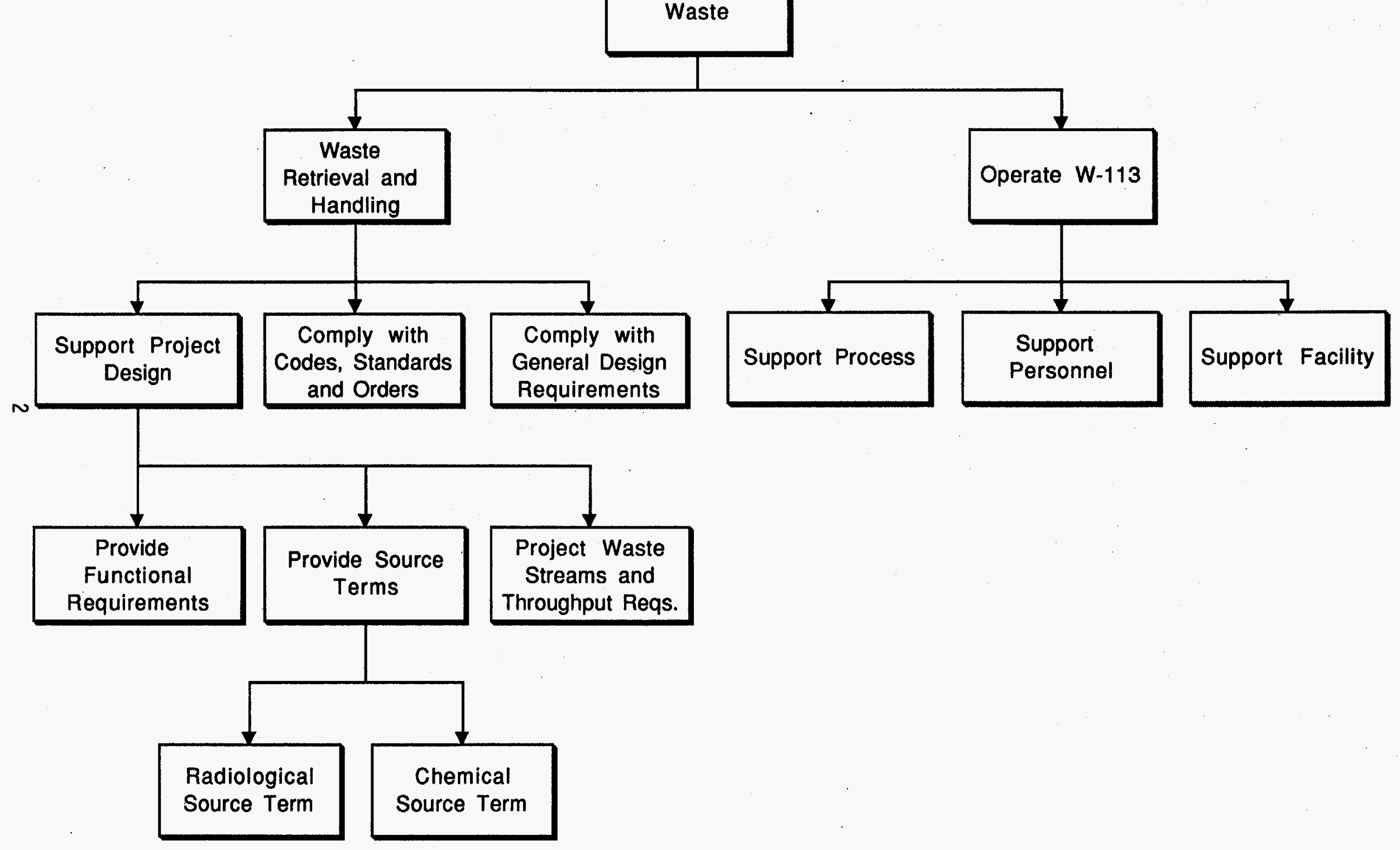


Fig. 1 Project W-113 Functional Analysis

Sht. 2 of 4

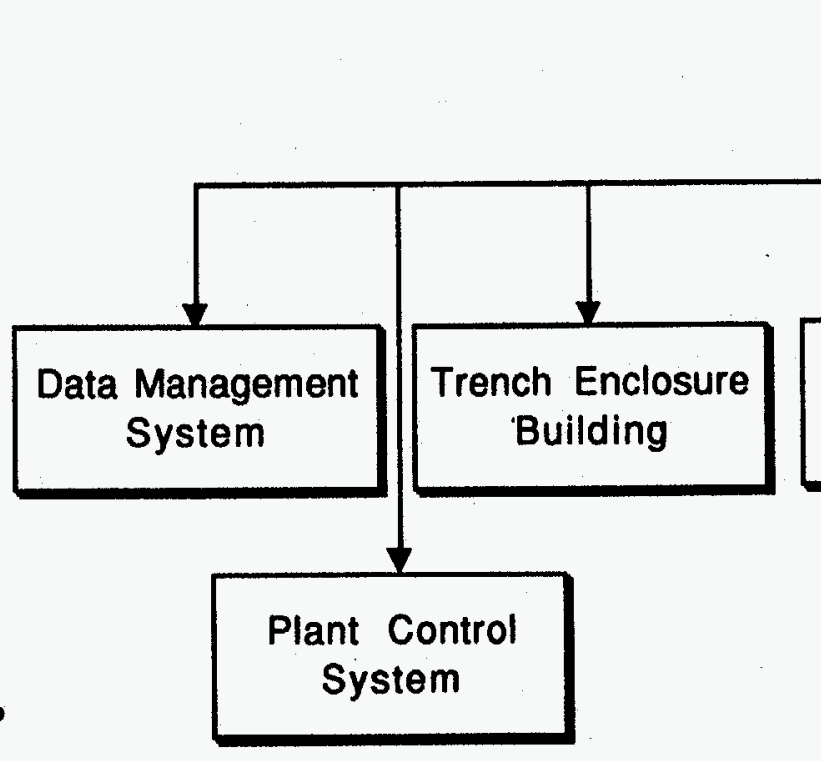

Support
Process
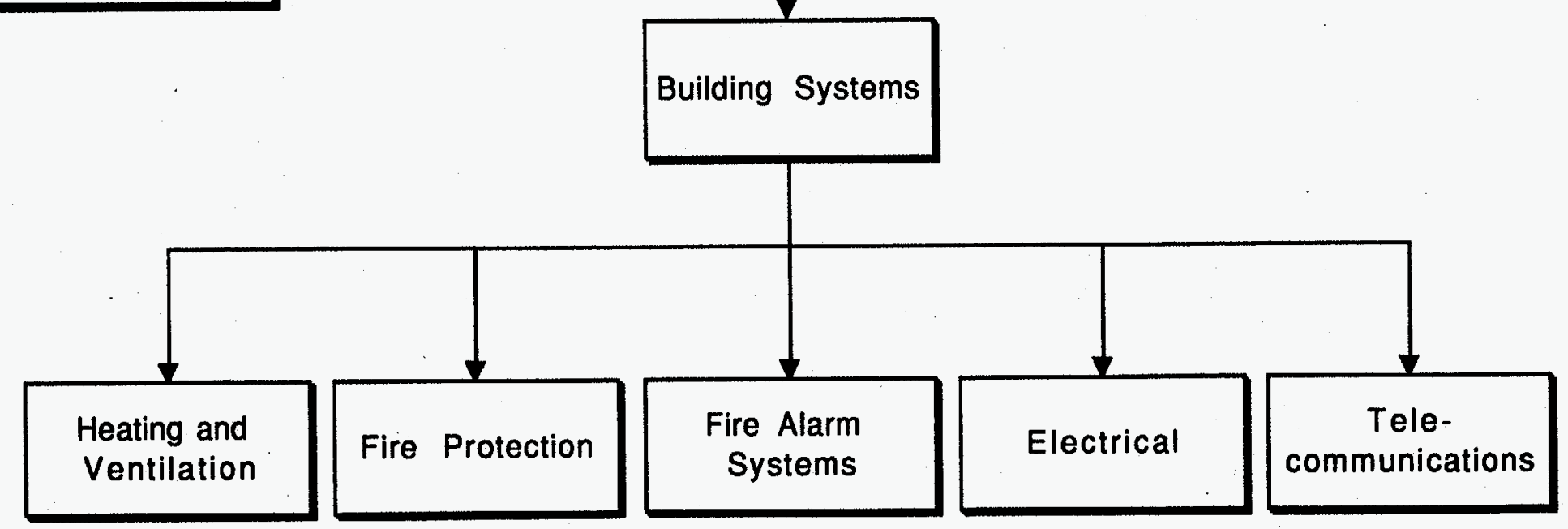
Fig. 1 Project W-113 Functional Analysis

Sht. 3 of 4

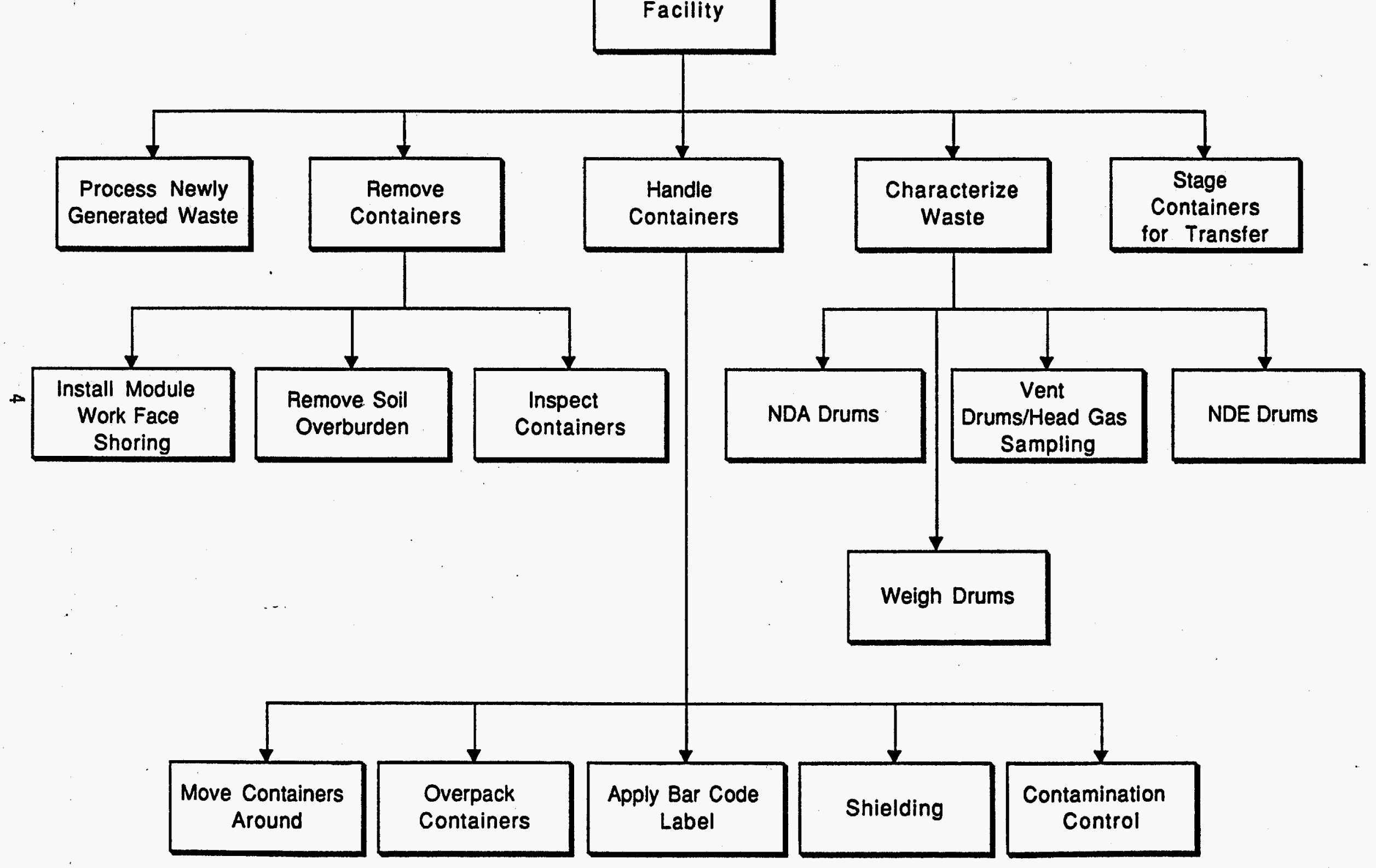


Fig. 1 Project W-113 Functional Analysis

Sht. 4 of 4
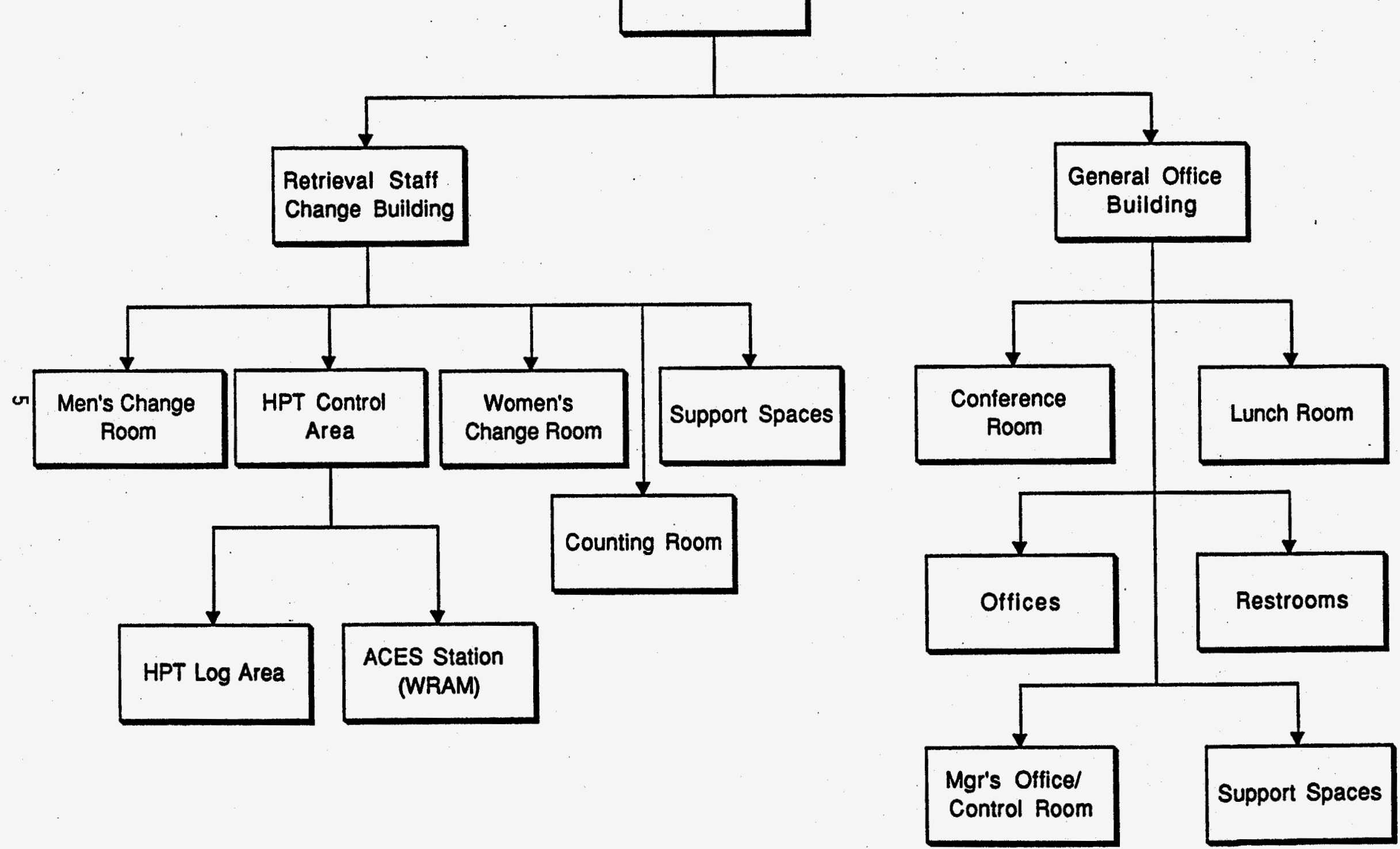


\subsection{PROJECT CRITERIA}

\subsection{PROJECT DESIGN BASES}

\subsubsection{Functional Requirements}

This document supplements WHC-SD-W113-FDC-001, Revision 2, "Functional Design Criteria for the Solid Waste Retrieval Facility Phase 1, Project W-113." The Supplemental Design Requirements Document (SDRD) shall not conflict with the FDC. The FDC shall govern when contradictions occur. The SDRD provides additional detailed requirements, summarizes baseline key Westinghouse Hanford Company (WHC) design guidance and establishes baseline technical agreements to be used in definitive design of the Solid Waste Retrieval Facility Phase 1, Project W-113.

The requirements provided in this document do not relieve the Architect/Engineer $(A / E)$ of any design initiative or responsibility. The information contained herein represents the WHC technical position based on experience with similar facilities and is in the interest of consistency with other DOE facilities where possible.

This document contains design bases and supplemental requirements which, if changed, could impact project cost or schedule. Therefore, deviations from this guidance must be made with WHC concurrence. Changes to this document will constitute a Level II change in accordance with established WHC change control procedure.

\subsubsection{Waste Feed Streams and Throughput Requirements}

Project $\mathrm{W}-113$ shall retrieve waste in Trench $4 \mathrm{C}-04$ with the waste containers types, mixed waste, and drum dose rates listed in the FDC, Appendixes $B, C$, and $E$, respectively.

Project $W-113$ shall support $p l a n s$ to retrieve waste in support of program plans that involve treatment, storage and disposal of a significant portion of TRU waste placed in trench storage after April 1978. It shall provide a feed stream for the Waste Receiving and Processing (WRAP) facility with ultimate treatment, storage, or disposal of the processed wastes in onsite and offsite facilities. Waste containers retrieved shall be sent to Project $\mathrm{W}-112$ for interim storage.

\subsubsection{Retrieval Operations}

Figure 2, Retrieval Operations Flow Diagram, supplements the one shown in the FDC, Appendix A, Figure 1.

\subsubsection{Drum Processing Operations}

A. Figure 3, Drum Processing Flow Diagram, i17ustrates the drum processing which is to be at a rate of 16 drums per shift $(5.5$ hours per shift) while not retrieving boxes. This detailed Drum Processing Flow Diagram supplements the one shown in the FDC, Appendix A, Fig. 2.0. 


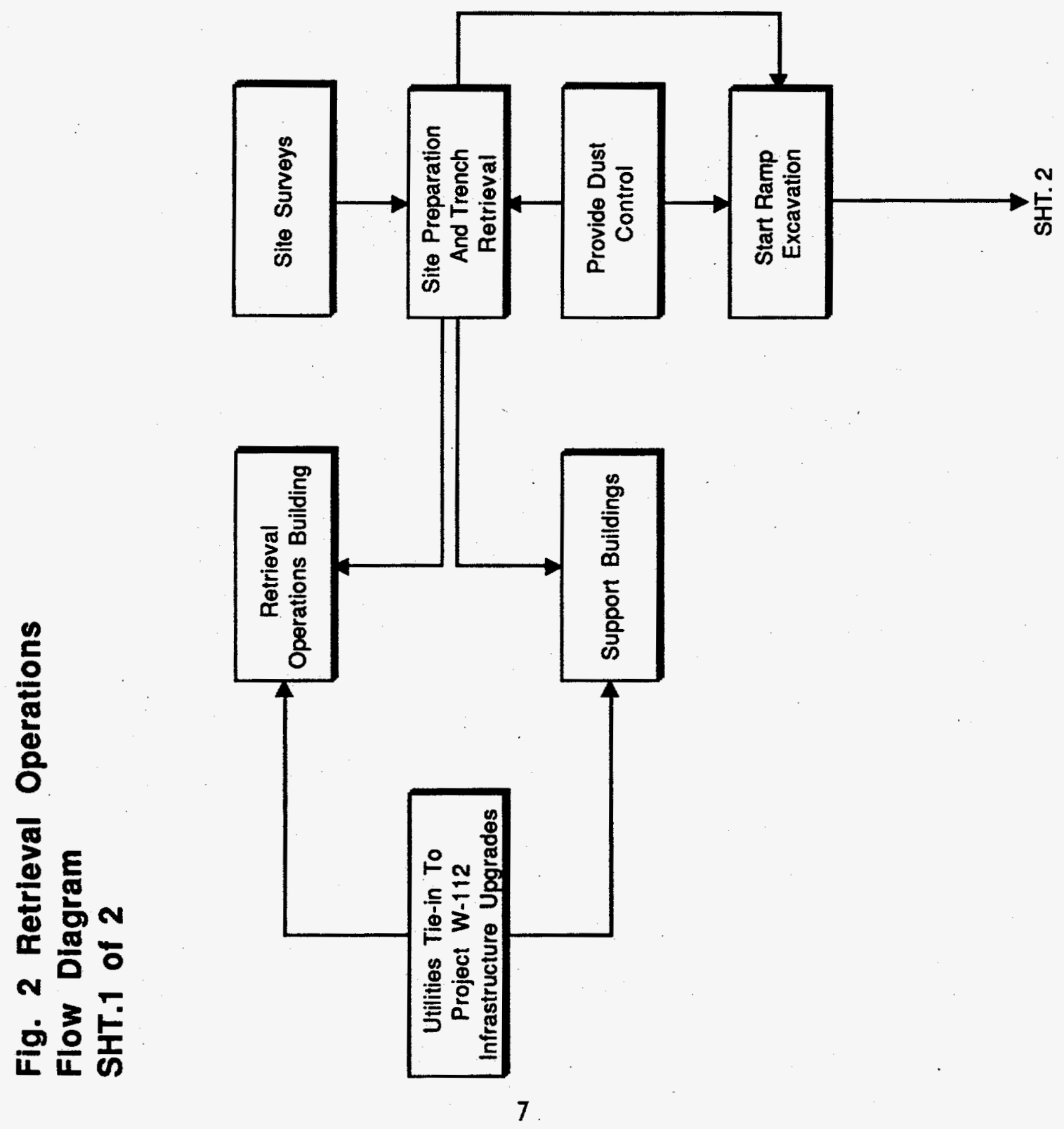


Fig. 2 Retrieval Operations

Flow Diagram

SHT.2 of 2

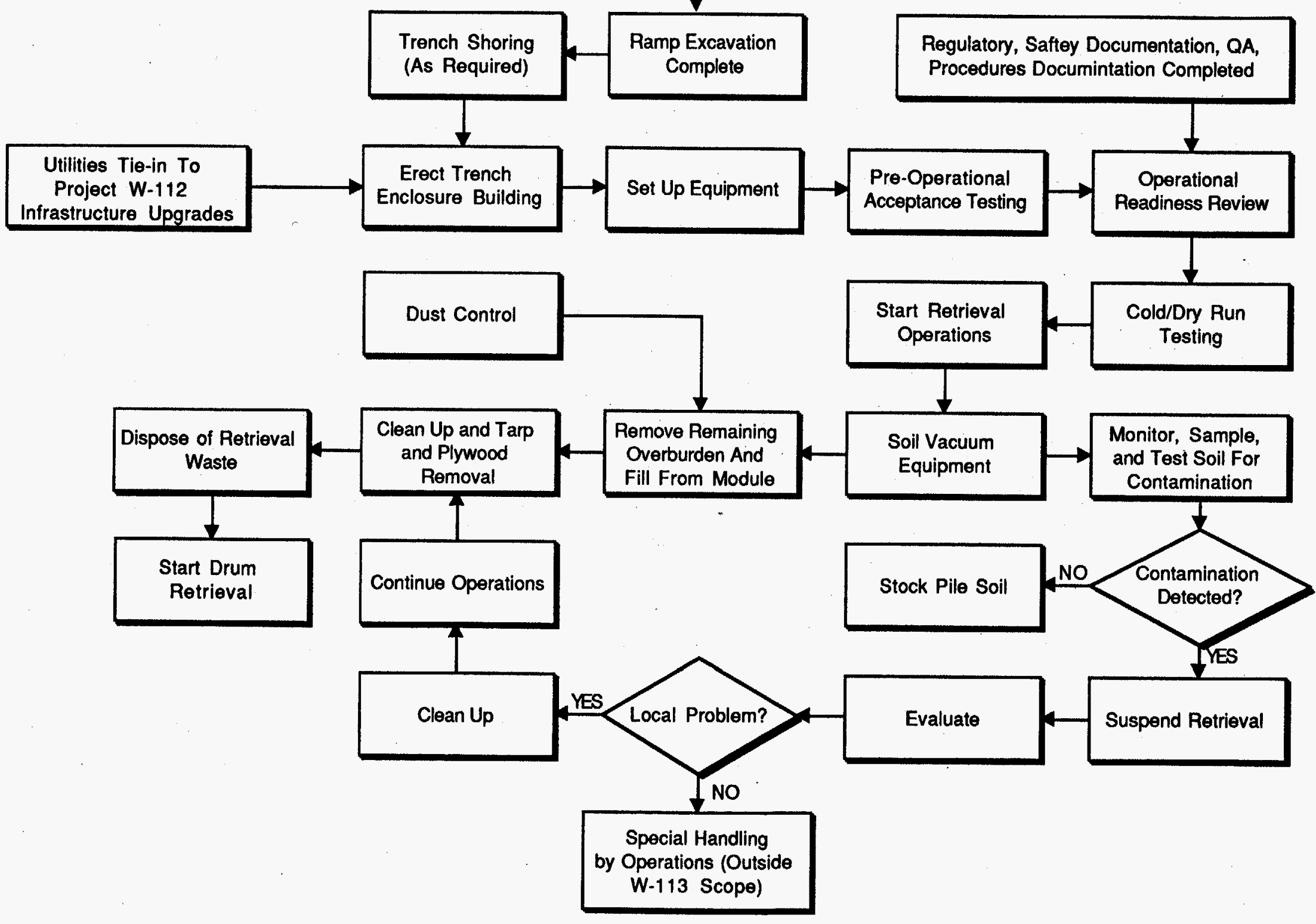


Fig. 3 Drum Processing Flow Diagra

SHT.1 of 2

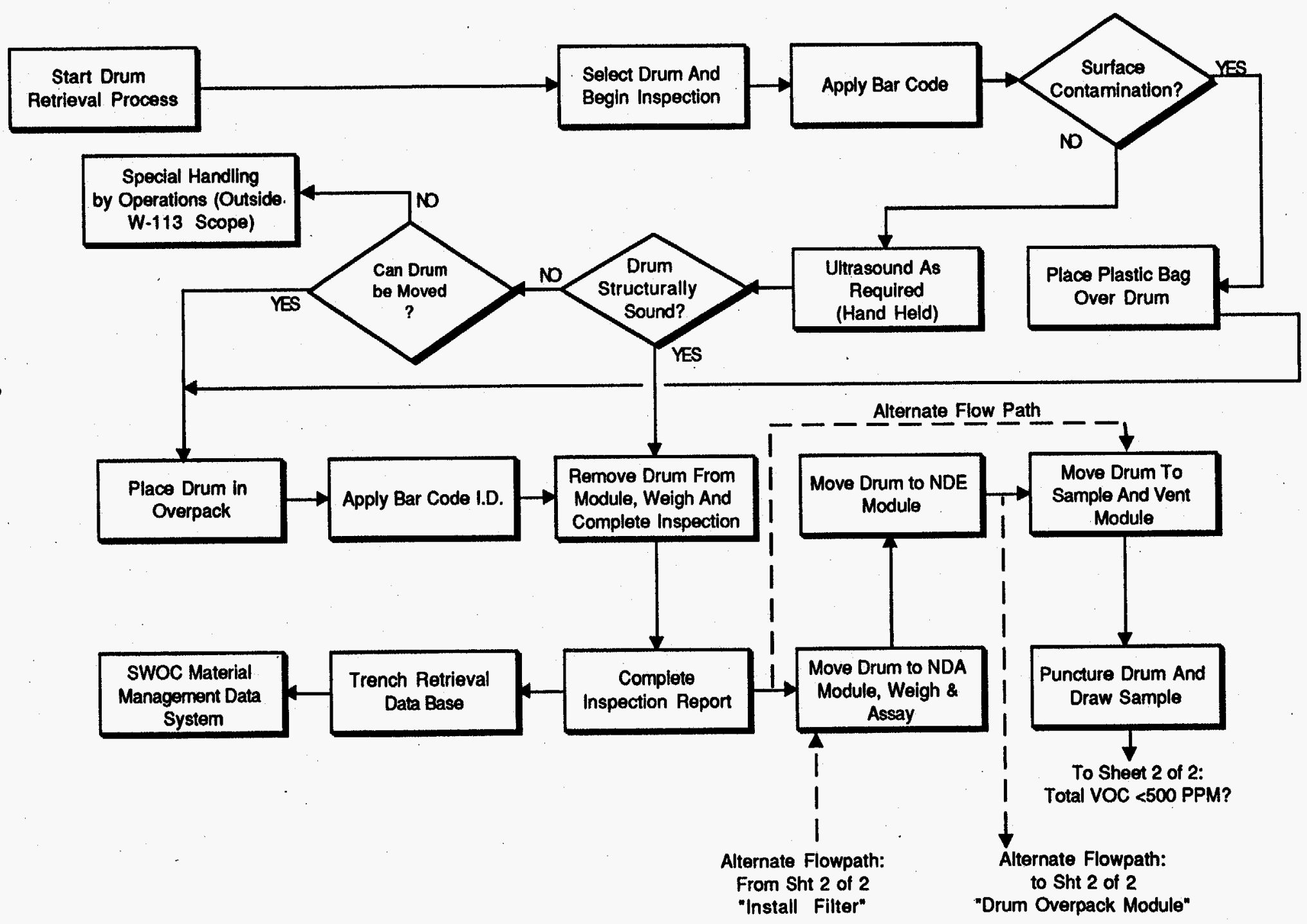


Fig. 3 Drum Processing Flow Diagra

SHT.2 of 2

From Sht 1 of 2:
"Puncture Drum

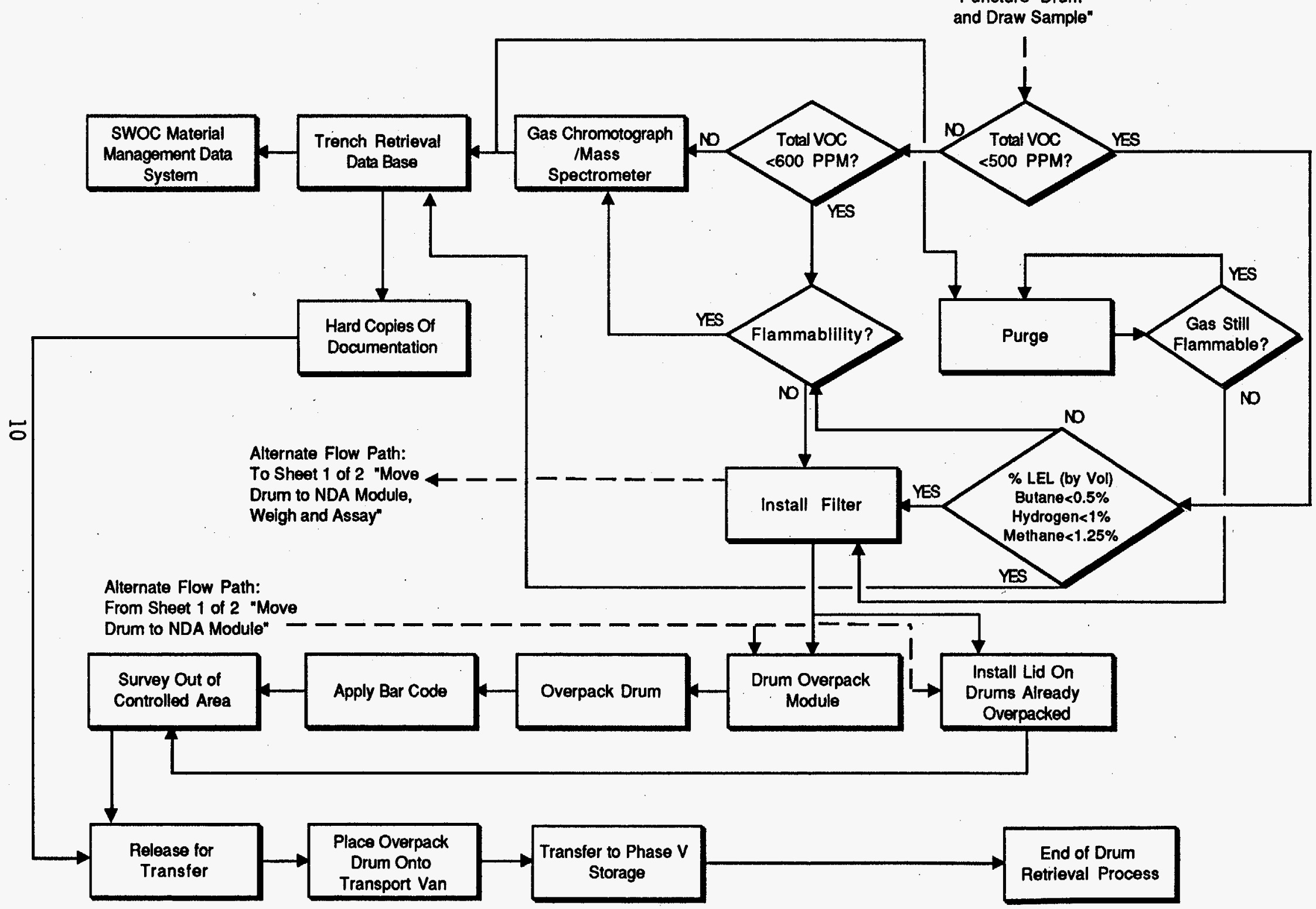


B. The process flow sequence for drums is as follows.

1. Select drum to be retrieved. Inspect integrity (in-place visual and ultrasonic testing), monitor, survey, weigh drum, record drum data, and barcode.

NOTE: Drum placed in overpack if found to be contaminated or not structurally sound, but with the overpack drum lid off.

2. Remove drum from the trench module.

NOTE: If the drums are to be vented first, move the drum to the drum venting/headgas sampling equipment. Perform Steps 8 and 9 first, then proceed to step 3 as before.

3. Place and weigh drum in the NDA equipment.

4. Perform NDA.

5. Move drum to the NDE equipment.

6. Perform NDE.

7. Move drum from the NDE to the drum venting/headgas sampling equipment.

8. Vent drum to obtain head gas sample.

9. Perform screening and if required sampling, analytical, and purging steps. Install drum lid filter when completed.

10. Move drum into drum overpack station and apply barcode label.

11. Survey overpacked drum out of the controlled area and label.

12. Load overpacked drums into transport $\operatorname{van}(s)$.

\subsubsection{Box Processing Operations}

A. Figure 4, Box Processing Flow Diagram, illustrates the box processing (when not retrieving drums) which is to be at an average rate of:

NOTE: This detailed Box Processing Flow Diagram supplements the one shown in the FDC, Appendix A, Fig.3.0.

1. 2 per shift (5.5 hours/shift) for smaller boxes (dimensions smaller than $\left.8^{\prime} \times 8^{\prime} \times 13^{\prime}\right)$

2. 1 per shift ( 5.5 hours/shift) for large boxes (dimensions greater than $\left.8^{\prime} \times 8^{\prime} \times 13^{\prime}\right)$ 


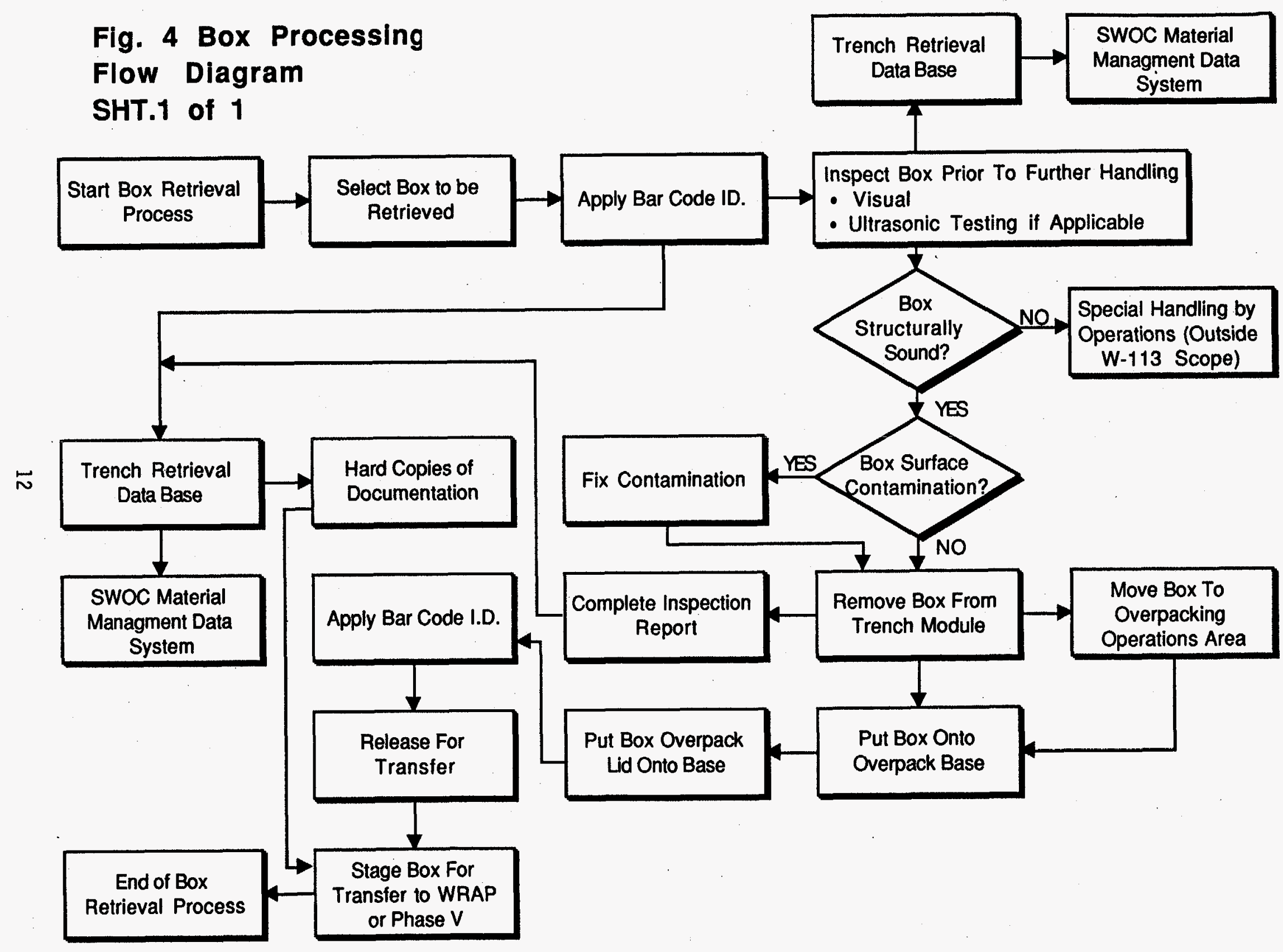


3. 1 per work week ( 5 days a week) for the $\left(7^{\prime} \times 12^{\prime} \times 16^{\prime}\right)$ boxes.

B. The process flow sequence for boxes is as follows.

1. Select box to be retrieved. Inspect integrity (in-place visual and ultrasonic testing), monitor, survey, record box data, and barcode.

2. Remove box from the trench module.

3. Move to box overpack area away from trench retrieval work area and place box on the baseplate of overpack box.

4. Complete overpack and barcode.

5. Survey box overpacks for transport and Tabel.

6. Transport overpacked boxes to the retrieved box storage facility of Project $W-112$.

\subsubsection{Source Terms}

Refer to WHC-SD-W306-TI-001, Rev.2, "Radiological and Chemical Source Terms for Solid Waste Operations Complex," (Boothe 1994) for the applicable source terms for Project W-113.

\subsection{PROCESS CRITERIA}

\subsection{RETRIEVAL AND MATERIAL HANDLING}

\subsubsection{Remove Containers}

\subsubsection{Remove Soil Overburden}

A. A detection system or device shall be used for estimating the location and depth of the buried containers prior to removing the top layer of soil. Soil or covering material shall be removed with extreme caution to prevent container rupture.

B. The dust control method/equipment to be provided during retrieval operations shall be any of the following: use of water tanks/ hoses or application of an approved spray.

C. The soil overburden shall be removed to within 1 foot of the waste in the trench before the trench enclosure building is erected. The soil shall be placed in a pile away from the trench. The soil shall be sampled for contamination before it is deposited in the spoils pile. 


\section{WHC-SD-W113-SDRD-001 REV 0}

D. Once the trench enclosure building is erected, the soil shall be removed from over the modules by a vacuum system, one module at a time and alongside the modules as drums are removed. The spoils pile shall be placed alongside the adjacent trench outside the enclosure. Large rocks that cannot be vacuumed shall be piled separately.

\subsubsection{Module Work Face Set-up}

A. Module work face shoring shall be provided only initially in front of the module to keep the pile from falling in case of a design basis earthquake (DBE) or an accident. Use shoring and/or stepping to prevent drums from falling more than 2 drums high.

B. A removable barrier should be installed in place of the module work face shoring when a step-up profile of the front 4 rows of drums is achieved.

C. The module work face shoring and removable barrier shall withstand the impact of a forklift/manlift travelling at a speed of $10 \mathrm{mph}$.

D. Electric unit heaters shall be provided as required to maintain the module work area ambient temperature above $35^{\circ} \mathrm{F}$.

\subsubsection{Inspect Containers}

A. Drums/containers shall be visually inspected to learn as much as possible about their condition before they are handled.

B. Drums/containers wall thicknesses shall be ultrasonically inspected as applicable before handling if structural integrity is suspect.

C. A method shall be developed to perform a visual inspection of the drum bottom with a minimum of drum handiing.

D. Visual inspections shall attempt to identify any of the following indicators.

1. Symbols, words, or other marks on the drum/container indicating that its contents are hazardous. Hazardous contents includes radioactive, explosive, corrosive, toxic, flammable, discarded laboratory chemicals, reagents, or other potentially dangerous materials in small containers.

2. Signs of deterioration (such as corrosion, rust, and leaks) or that the drum/container is under pressure (such as swelling and bulging).

E. The results of the preliminary visual and ultrasonic inspection shall be used to classify the initial condition of the drums and containers (i.e., radioactive, leaking/deteriorated, bulging, explosive/shock-sensitive, and/or contains small individual containers of laboratory wastes or other dangerous materials). 
F. Unlabelled containers shall be considered to contain hazardous materials and handled as such, until sampled.

G. Containers under pressure, as evidenced by bulging or swelling, shall not be moved until such time as the cause for excess pressure is determined. Appropriate mitigating containment design features and/or procedures per the safety assessment recommendations [(Section 3.2.1 (A)] have been implemented to protect employees from explosive relief of the drum. For example, non-sparking type material handling equipment and hand tools maybe required to prevent sources of ignition.

H. WHC supplied 85-gallon overpack or containers and suitable quantities of proper absorbent material shall be kept available and used in areas where spills, leaks, or ruptures may occur.

\subsubsection{Drum Removal}

The method of drum removal from a module shall be as follows.

A. After the overburden is removed from one module of drums, a method shall be put in place to keep the pile from falling in case of a design basis earthquake (DBE) or an accident during waste retrieval (see Section 3.1.1.2, Module Work Face Set-up).

B. Inspect the drum in-place before removing from the module. A person in the aerial platform shall inspect the drums and attach the grapple to a drum. The drum grappling equipment shall be attached to a jib crane or similar hoist positioned to remove drums from the module. Drum-weighing equipment shall be provided as an integral part of the drum hoisting/grappling equipment for weighing drums before removing from trench.

C. The 110-gallon drums shall be removed from the module in a similar fashion as the 55-gallon drums and placed in box overpacks.

\subsubsection{Box Removal}

The method of box removal from a module shall be as follows.

A. A tractor-trailer rig shall be at the box overpacking area outside the trench enclosure building. The overpack baseplate for the box shall be on the trailer. The top of the overpack shall be removed for later use. The base shall remain on the trailer.

B. Inspect the box in-place before removing from the module. The person in the aerial work platform shall inspect the boxes, apply barcodes and set the rigging. The diese1-driven forklift truck shall lift the box from its stored position.

C. The box shall then be removed from the module, moved to the trailer containing the overpack base, rotated if necessary, and lowered onto the overpack base. While reassembling the overpack, dunnage shall be placed around the box to keep it from shifting. 


\subsubsection{Process New1y Generated Waste}

Plastic covering and plywood removed from the modules during retrieval shall be surveyed and disposed of per the Solid Waste Operations operating procedures to keep work areas clear.

\subsection{HANDLE CONTAINERS}

\subsubsection{Equipment/Operational Requirements}

A. Handling operations shall reduce operator radiological and industrial hazard exposure to As Low As Reasonably Achievable (ALARA). Operators shall be protected at all times from potential drum explosion. An assessment that addresses safety of the retrieval worker while performing work around the drums should determine what mitigating design features are required to protect workers from potential drum explosions.

B. Site operations and equipment layout shall be organized to minimize the amount of container movement.

C. Continuous communications (i.e., portable two-way radios, hand signals, telephones) as appropriate shall be maintained during the container retrieval and handling operations.

D. All hydraulic, mechanical, and electro-mechanical power transmission devices shali be designed and specified to have a $25 \%$ minimum derate, i.e., the performance requirement shall not exceed $75 \%$ of the devices capabilities.

E. Material handling equipment used to transfer drums and containers shall be selected, positioned, and operated to minimize sources of ignition of vapors released from drums or containers during handling accidents.

F. A 1-ton jib crane (manually controlled and electrically operated) installed at the drum overpacking station shall be used to position the drums in the overpack drum.

G. Electric fork ift trucks provided with drum grappling attachments shall be used for drum handling to and from the NDA, NDE and the drum venting/head gas sampling equipment. Forkl ift trucks selection shall be based on requirements specified in OSHA, 29 CFR 1910.178 and ANSI/NFPA 505.

H. An electrically-powered aerial work platform (man-lift) shall be used for lifting personnel to the working level of the storage module. The personnel on the manlift shall remove the plywood and tarpaulin, attach the drum grapple, or attach the 1 ifting apparatus to the drum. 
I. Diesel-powered truck and flatbed trailer are to be furnished by the Operating Contractor to transport the boxes from the lag staging area to Project $W-112$ storage or WRAP facility.

J. A diesel-powered forklift truck with a 15-ton capacity (sized to lift the largest box) shall provide the majority of the box removal work in the trench and box overpacking will be done outside the trench.

K. Other hoisting and rigging requirements are as specified in the DOE-RL-92-36 "Hanford Site Hoisting and Rigging Manual."

\subsubsection{Overpack Containers}

A. Refer to WHC-SD-TP-PDC-014, Rev. 0, Packaging Design Criteria, Project W-113 Box Packaging, (McCormick 1993) for requirements for the boxes overpacking containers.

B. A WHC Safety Analysis Report for Packaging (SARP) shall be written to ensure that the box overpacks as designed will be approved for use as intended.

C. The quantities and inside nominal dimensions of the 5-box overpacks will be:

1. (1) $\ldots \ldots 16^{\prime} \times 7^{\prime} \times 12^{\prime}$

2. (9) $\ldots \ldots 12^{\prime} \times 8^{\prime} \times 7^{\prime}-1^{\prime \prime}$

3. (1) $\ldots \ldots 12^{\prime}-6^{\prime \prime} \times 4^{\prime}-3^{\prime \prime} \times 3^{\prime}-10^{\prime \prime}$

4. (28) $\ldots \ldots 7^{\prime} \times 6^{\prime} \times 6^{\prime}$

5. (3) $\ldots \ldots 6^{\prime} \times 6^{\prime} \times 6^{\prime}$

D. The design of 85 gallon drum overpacks is not part of Project W-113.

E. Space shall be provided for a drum overpacking station at the trench enclosure building.

F. A 1-ton jib crane provided with special drum handlers shall be used to overpack drums before they are shipped to the transport vans. Drum-weighing equipment shall be provided as an integral part of the overpack station for weighing overpacked drums before shipping them to the transport van(s).

G. Electrical power supply for the l-ton jib crane shall be by a cable and plug connection to a power receptacle installed inside the trench enclosure building within which the overpacking takes place. 


\subsubsection{Apply Barcode Label}

A. A barcode system shall be used to facilitate tracking and inventory control of the retrieved waste containers and overpacks. This system will allow all known retrieval data to be entered into the DMS.

B. Discrete barcoding will be applied to the containers at the retrieval site. Both the waste containers and the overpacks will have affixed a unique barcode identifier.

C. The barcode identification labels will be placed at three locations about 120 degrees apart within five inches of the bottom, and 1 label on the top surface of each drum. Labels are required on all sides and the top of rectangular containers. These barcode 1 abels shall accompany both the waste containers and overpacks throughout appropriate process steps.

\subsubsection{Shielding}

A. Verify by means of shielding calculations, if shielding shall be required around the drum modules for full-time occupancy of the trench. Any required shielding design will be provided by the $A / E$.

B. Shielding shall be provided inside both the NDE and NDA mobile unit to provide attenuation factors to assure equipment accuracies. This is intended to be above and beyond the shielding which comes with the equipment.

C. No special shielding devices are required for the box overpacks.

\subsubsection{Contamination Control}

A. Surveying, packaging and disposal of contaminated retrieval equipment (e.g. tarps, plywood, etc.) will be provided by Solid Waste Operations.

B. Decontamination shall be performed in an area that shall minimize the exposure of uncontaminated employees or equipment to contaminated employees or equipment.

C. Personnel decontamination facility will not be provided by Project W-113.

D. Plastic overbags will be placed over contaminated drums from retrieval before further processing.

E. Drums with suspect structural integrity will be put in drum overpacks before further processing. 


\subsection{CHARACTERIZE WASTE}

\subsubsection{NDA Drums}

A. The W-113 NDA equipment will be similar in function to the NDA equipment to be used in WRAP 1 , except it will be transportable and housed in a common single-trailer mounted enclosure shared with the NDE equipment.

B. Refer to WHCs NDA/NDE interface control drawings H-2-823422 thru H-2-823431 for the NDA/NDE mobile trailer design requirements.

\subsubsection{Weigh Drums}

Drum weighing equipment shall be provided as an integral part of the NDA equipment and with a weight limit of 1 ton.

\subsubsection{Vent Drums/Head Gas Sampling}

A. To assure the project retrieval rate of $16 \mathrm{drums} / \mathrm{sh}$ ift, two (2) drum venting/head gas sampling equipment shall be provided in the same trailer as described in Item $\mathrm{C} .4$ below.

B. The design requirements as stated on the cis engineering study report (Ocampo 1993), shall be used in the drum venting/head gas sampling equipment design and procurement specifications.

C. The following design requirements shall be provided for the WHCsupplied CVS equipment mobile trailer:

1. Audible and visual warning signals shall be activated anytime one of the two CVS equipment is operating.

Signalling devices will be installed on the exterior wall of the mobile trailer.

2. The electrical power supply for the CVS equipment shall be connected by a cable and plug to a 100A, 3-pole, 4-wire, grounding-type $480 \mathrm{~V}$ power receptacle installed inside the trench enclosure building. A similar $480 \mathrm{v}$ power receptacle installed outside the trench enclosure building shall be provided when the CVS is outside the trench during "startup" operations.

3. A three-phase 75 KVA 480-120/240 Vac step-down transformer and a three-phase $120 / 240$ Vac distribution panelboard will be required on the portable trailer to provide the $120 / 240$ Vac power, control and instrumentation requirements. Transformer and distribution panelboard are governmentfurn ished equipment.

4. The maximum dimensions of the CVS as a mobite unit are 12.2 $\mathrm{m} L \times 2.4 \mathrm{~mW}(40 \mathrm{ft}$. $L \times 8 \mathrm{ft}$. W) overall. The trailer will be provided with hydraulic load levelers. 
5. Stairs for personnel access to the CVS systems will be from the same side of the mobile trailer. Access may also be from the rear.

D. The drum venting/head gas sampling equipment will have its own data storage capability.

\subsubsection{NDE Drums}

A. The W-113 NDE equipment will be similar in function to the NDE equipment to be used in WRAP 1 , except it will be transportable and housed in a common single-trailer mounted enclosure shared with the NDA equipment.

B. Refer to WHC NDA/NDE interface control drawings H-2-823422 thru $\mathrm{H}-2-823431$ for the NDA/NDE mobile trailer design requirements.

\subsection{STAGE CONTAINERS FOR ON-SITE TRANSFER}

A. A 1-ton jib crane shall be used to overpack drums before they are transferred to Project $W-112$ storage or the WRAP facilities.

B. Standard Solid Waste Operations operating procedures for overpacking drums should cover filler/bracing to prevent impact between drum and overpack. The overpacked drum will be weighed before it is transferred to Project W-112.

c. The drums, waiting for transfer to Project $W-112$ storage will be directly loaded into van(s), provided by Solid Waste Operations. Stacking of drums is not permitted.

\subsection{PLANT CONTROL SYSTEM}

Refer to WHC-SD-W306-SDRD-001 Rev.0, Supplemental Design Requirements Document Solid Waste Operations Complex, (Ocampo 1994) for the Project W-113 Plant Control System (PCS) general functional requirements. The Project $\mathrm{W}-113$ PCS will have a limited functionality (used mainly for monitoring and annunciating selected facility alarm conditions) as compared to the WRAP $2 A$ and Project $\mathrm{W}-112$ (PCS).

\subsection{DATA MANAGEMENT SYSTEM}

Refer to WHC-SD-W306-SDRD-001 Rev.0, Supplemental Design Requirements Document Sol id Waste Operations Complex, (Ocampo 1994) for the Project $W-113$ Data Management System (DMS) and interfaces to the following Project $\mathrm{W}-113$ subsystems: CVS Head Gas Sampling, NDE, NDA, Ultrasonic Testing, Visual Inspection, Bar Code Readers, and Alarm Annunciation. 


\subsection{RADIATION AND AIR MONITORING}

A. Radiation and air monitoring will specified by the Radiation Work Permit (RWP) as part of the Work Plan for waste drum retrieval operations.

B. At and/or near the drum module workface, the HPT will monitor for direct radiation with hand held instrumentation. Qualitative evaluation of smears will be determined using hand held survey instruments. Quantitative evaluation of smears, if required, will be performed in the counting room of the retrieval staff change building.

C. In order to release drums and boxes from the Trench Enclosure Building (an RCA), alpha and beta/gamma smears to determine that the containers are below release levels for contamination will be monitored by the use of both beta/gamma and alpha hand held survey instruments. An examination area near the exit of the Trench Enclosure Building, where the smears are monitored, will. require a reduced background to obtain a proper minimum detectable count rate (MDRC).

D. The RWP will require air samples to be taken to determine the airborne contamination in the working area. Portable air sampling equipment will be required. Two high-volume (>8 cfm) portable air samplers need to be available. These units would normally be ac line powered. Two low-volume ( $>2 \mathrm{cfm}$ ) gooseneck-type samplers need to be available. These units are hand-carted vacuum pumps with rotameter, elevated sampling heads, and are AC-line powered.

E. The ability to provide timely (less than 15 minutes) evaluation of these air samples will require a Radon discriminating alpha counting system. This system must be able to quantify the amount of transuranic alpha on an air sample filter paper and provide a lower limit of detection (LLD) of $2 . \mathrm{E}-12 \mathrm{uCi} / \mathrm{ml}$ from a $400 \mathrm{cf}$ air sample. This counter should also have the ability to count contamination smears.

F. Ambient area sampling for toxic gases shall be provided inside the trench enclosure building retrieval operations work areas (GFE).

G. HP monitors and toxilogical alarms for off-shift notifications will be to the existing 200A Computer Automated Surveillance System (CASS) presently located at the 200E Area, 2750E Building. 


\subsection{FACILITY CRITERIA}

\subsection{BUILDING STRUCTURES}

\subsubsection{Trench Enclosure Building}

A. The trench enclosure building structural design criteria for a moderate hazard facility shall be per SDC-4.1 Section 3.2.

B. Personnel and emergency access to the trench shall be handled by a movable metal stair structure: Where doors or gates open directly onto a stairway, a platform shall be provided extending at least 22 inches beyond the swing of the door.

C. A second movable stair shall be provided on the south side of the trench enclosure building as a means of accessing the exit doors.

D. The trench enclosure building shall be designed such that equipment access and clearances and material handling and staging are accommodated without creating safety hazards.

E. The trench enclosure building cross sectional dimensions shall be determined by minimum requirements for retrieving and handiing the boxes from the waste modules.

F. A step-off pad and soiled laundry collection bins (soiled anti-Cs clothing storage) shall be provided inside the trench enclosure building with access designed to preclude spread of contamination.

G. Confinement ventilation will not be required for the trench enclosure building.

\subsubsection{Retrieval Operations Building}

A. The retrieval operations building shall be provided with adequate ventilation, electrical and fire protection as required and located as close as possible to the trench enclosure building.

B. Confinement ventilation will not be required for the retrieval operations building.

C. Space allocation at the retrieval operations building shall be as follows.

1. Space for a 1-shift (16 drums) supply of WHC-supplied overpack drums is to be provided.

2. Space for a battery charging equipment is to be provided. There should be sufficient ventilation in the battery room to prevent hydrogen gas buildup greater than $1 \%$ by volume. 
3. Space for storage of other materials and tools is to be provided. Other materials and tools include, but are not limited to, the following; spill control materials, personnel protective equipment for the job, and field equipment checkout room.

4. Space shall be provided near the building for the box overpacking station on the tractor trailer used for transporting it to Project W-112.

D. A parking area just west of Dayton Avenue for use by the retrieval operations personnel is required. Use of existing parking lot for M0-281 should be considered before new parking lot is provided.

E. The design and construction of the proposed Denver Avenue (west of Dayton Avenue) for bypass around Dayton Avenue shall be provided by Project $W-112$ infrastructure upgrades.

\subsubsection{General Office Building}

\subsubsection{Offices}

A. Office spaces shall be provided for the following retrieval operations administrative staff: 1 manager/supervisor, 1 secretary/clerk, 2 technical staff, and a turnaround office.

B. Office spaces shall be provided for duplicating, fax machines, and storage of office supplies.

C. All offices except for the secretary/technical services shall be hard walled.

\subsubsection{Conference Room}

A. One conference room shall be provided with 20 persons minimum seating capacity to be used for training and meetings.

B. Conference room shall be provided with dedicated electrical outlets required for the equipment to be provided in the room by others.

C. Conference rooms shall be supplied with telephone and HLAN.

\subsubsection{Restrooms}

A. An exhaust ventilation system shall be provided in the rest rooms.

B. Initial complement of furnishings for the rest rooms shall be provided.

C. GFI electrical outlets shall be provided where required by the NEC.

D. A drinking fountain shall be provided in the hallway adjacent to the restrooms. 


\subsubsection{Lunch Room}

A. Lunch room shall be designed to accommodate a maximum single shift staff of 6 female and 14 male personnel.

B. GFI electrical outlets shall be provided where required by the NEC.

C. An exhaust ventilation system shall be provided in the lunch room.

D. Initial complement of furnishings for the lunch room shall be provided.

E. Space and electrical outlets for the following appliances shall be provided: 2 refrigerators, 1 range with exhaust hood, 2

microwaves, vending machines (machines NIP), and an under-counter dishwasher.

\subsubsection{Retrieval Staff Change Building}

A. A women's changeroom shall be designed to accommodate a maximum single shift staff of 6 female personnel.

B. A separate men's changeroom shall be designed to accommodate a maximum single shift of 14 male personnel.

C. Each of the separate change rooms shall be provided with the following: a corresponding number of lockers, rest rooms located in the locker room but not in areas requiring anti-Cs, showers shall be provided with exhaust ventilation system. The exhaust ventilation system will not require HEPA filters. A half-body personnel contamination survey equipment shall be installed in the buffer area for self-survey prior to exit from building.

D. An initial complement of furnishings for each of the separate change rooms shall be provided.

E. Two clean laundry delivery areas shall be provided, with access designed to preclude spread of contamination. There are 2 types of clean laundry: 1) clean bath towels and 2) clean anti-Cs clothing. They are washed, shipped, and stored separately.

F. A counting room shall be provided for smear counting equipment and portable radiation meter storage. The counting room shall be located in the RCA (radiological controlled area) adjacent to the change rooms.

G. Anti-Cs clothing change areas shall be designed and integrated with non-anti-Cs clothing change areas to allow unimpeded movement of personnel to work areas without co-mingling of anti-Cs clothing clad workers with non-anti-Cs clothing clad workers.

H. Provide a HPT control area with sufficient spaces for the following: $\log$ area for 4 HPTS and HPT ACES (formerly WRAM) station. 
I. A janitor closet shall be provided with a mop sink, shelving for janitorial supplies, 3 hot water heaters, and space for a telecommunication terminal backboard.

I. The retrieval staff change building is expected to be placed as close to the trench enclosure building's initial position as possible.

J. Confinement ventilation will not be required for the retrieval staff change building.

\subsection{EQUIPMENT DESIGN REQUIREMENTS}

\subsubsection{U1trasonic Testing Equipment}

The following design requirements shall be used in the procurement specification of the ultrasonic testing equipment.

A. A hand-held, portable, and battery-powered with back-up battery provided.

B. The capability to measure wall thickness and extent of corrosion even when only one side is accessible with an accuracy of $( \pm 0.5 \%$ of reading).

C. The capability to measure wall thicknesses from a \#20 gauge for drums up to $0.6 \mathrm{~cm}(1 / 4$ inch) for metal boxes.

D. The capability to measure wall thicknesses even when painting or coating is present provided painting or coating is in good condition and its thickness does not exceed $(0.012$ inches $0.3 \mathrm{~mm}$ ).

E. The capability to automatically calculate and display the maximum, minimum, average and standard deviation values.

F. Will be provided with audible and visual alarm indicators when thickness measurements go out of user-set tolerances.

G. The capability to transfer data and statistics to a printer or personal computers.

H. Will be provided with a large, easy to read LCD display of thickness measurements.

I. The capability to be used to permit access to some drum walls, while drum is still in the module, for initial checks.

J. The capability to measure wall thicknesses with minimum surface preparation by using a wire brush to remove surface corrosion but will not require grinding to bare metal. 


\subsubsection{Soil Vacuum Equipment}

The following design requirements shall be used in the procurement specification for the soil vacuum equipment.

A. The capability to remove 15 tons of soil per hour and be portable.

B. Will be provided with overload protection for the vacuum pump motor.

C. Soundproofed to less than 85 DBA.

D. Will be provided with a weatherproof. enclosure.

E. Will be provided with a HEPA-filtered exhaust system and radiation monitoring equipment.

\subsubsection{NDE Equipment}

The following design requirements shall be used in the procurement specification for the NDE equipment.

A. The NDE system shall consist of a shielded enclosure (vault), manipulation system, single highly stabilized 450Kv $x$-ray source, high resolution $x$-ray image intensifier, digital linear array, optical coupling, and monochrome closed circuit TV system.

B. The entire system shall be housed in a common single trailermounted enclosure shared with the NDA equipment described in Section 4.2.4, capable of providing protection for the equipment from blowing dust, snow, and water leakage. The unit shall be designed to be rugged or easily secured for transport and shall be capable of being stored on site. It must be able to accept and present 55-gallon drums or 85-gallon drum overpacks at a loading and/or unloading station so that a fork 1 ift fitted with a drum handler can be used to place or receive the drum.

C. The resolution and penetration of the examination system using the image intensifier shall be assessed using the ASTM penetrometer in accordance with ASTM-E-94. The acceptance criteria shall be the visibility of an ASTM penetrometer of 2-2T sensitivity through a steel thickness of 2.5 inches on the live video monitor with no image processing or enhancement.

D. The following radiation and shielding requirements shall be considered.

1. The maximum allowable dose rate at any accessible area five (5) $\mathrm{cm}$ from the outside surface of the enclosure shall not exceed $0.5 \mathrm{mrem} / \mathrm{hr}$. 
2. The dose rate 1 imits shall be based on the operation of the $x$-ray device at those combinations of $x$-ray tube potential, current, beam orientation, and conditions of scatter radiation which will produce the maximum $x$-ray exposure at the external surface of the enclosure.

3. Reliable fail-safe safety interlocks shall be provided to prevent access to the enclosure during irradiation.

E. The following control system requirement shall be considered.

1. The image intensifier and drum movement systems shall permit the following controls: up, down, rotate, and transverse sideways (to the edge/tangent of the drum).

2. It shall have the capability to "jog" the drum in order to facilitate the identification of free liquids.

3. The manipulation scanning and drum movement shall feature variable speeds.

4. A feature shall be provided to enable the operator to properly align the drum with the imaging system.

F. A red rotating beacon warning device shall be provided in the $x$-ray vault (room). The beacon will be activated anytime the system is in use.

\subsubsection{NDA Equipment}

The following design requirements shall be used in the procurement specification for the NDA equipment.

A. The NDA system shall consist of a passive/active neutron interrogation system that shall make the necessary measurements in order to determine the radionuclide contents of 55-gallon and 85-gallon overpack drums and to certify them as low-level waste (LLW) or transuranic (TRU) waste. The PAN system shall adjust its scanning program for both 55-gallon and 85-gallon overpack drums.

B. The active portion of the PAN system shall be provided with the following.

1. A neutron generator to provide short (5-10 sec) bursts of thermat neutrons to "interrogate" the waste. The thermal neutrons induce fissions of fissile isotopes such as Pu-239 and Am-241, resulting in a burst of fission spectrum neutrons being emitted by each fissioning nucleus.

2. Cadmium shielded detectors shall be provided to reject the thermal neutrons, but detect about $10 \%$ of a 11 fission spectrum neutrons. 
3. A set of thermal flux monitors (one cadmium shielded the other bare) shall also be located in the assay chamber, and are used to determine the Absorption Index of the waste.

c. During the active assay mode, the PAN system shall be able to differentiate between neutrons generated from spontaneous and from induced fissions.

D. The passive portion of the PAN system shall be use high-efficiency neutron detectors and coincidence counting techniques to quantify the number of time related neutrons being emitted by spontaneous fissioning isotopes such as $\mathrm{Pu}-240$. This side of the counting equipment shall be utilized for those drums which are determined by active neutron interrogation to be TRU waste, and will produce a "Pu-240 equivalent" value which can then be combined with the $\mathrm{Pu}$ isotopic ratio determined from characterization data to give a total Pu content.

E. During the passive mode, the PAN system shall make coincidence measurements to be able to differentiate between neutrons generated from fissions and those from alpha, $n$ reactions. coincidence counting electronics shall be of the shift register type (or equivalent).

F. The PAN system shall have the following measurement sensitivity.

1. The lower limit of detection for TRU measurement shall be sufficient to enable LLW categorization, whether a drum contains greater or less than $10 \mathrm{nCi} / \mathrm{g} \mathrm{TRU}$.

2. The system shall be able to detect the presence of $U-235$ and $\mathrm{Pu}-239$ in concentrations as low as $1.0 \mathrm{nCi} / \mathrm{g}$, in a heavy matrix, in the presence of millicuries of fission and/or activation products, with an average background of less than $50 \mathrm{microrem} / \mathrm{hr}$ and within the assay time duration of 10 to 15 minutes.

\section{NOTES:}

a. To "detect" is defined as being able to determine that the net counts exceed three times the one sigma background.

b. "Heavy matrix" means high density (12-100 1b/cu.ft) waste consisting of such things as concrete, soil, steel, lead, depleted uranium and failed equipment.

3. The system shall have an upper assay limit of 500 grams of fissile material.

G. At 1 east $67 \%$ of the measured Pu-239 values shall be within $\pm 5 \%$ of the mean value of all measurements when repeatedly assaying a single drum containing $100 \mathrm{mg}$ of plutonium in laboratory waste. repeated assay operations shall include loading and unloading the drum from the measurement system. 
NOTE: "Laboratory waste" means low density (up to $6 \mathrm{lb} / \mathrm{cu} . \mathrm{ft}$ ) waste containing such things as paper, rags, rubber gloves and some glass, but without chlorinated plastics or other neutron absorbers or high atomic number materials.

H. The following are the total measurement uncertainty (TMU) requirements for the system based on uniformly distributed radionuclides in drums of homogeneous waste of either "moderate absorber" or "lab waste" content:

Table 4. TOTAL MEASURENENT UNCERTAINTY (TMU).

\begin{tabular}{|l|l|l|l||}
\hline $\begin{array}{l}\text { MEASUREMENT } \\
\text { METHOD }\end{array}$ & $\begin{array}{l}\text { MEASURAND } \\
\text { CONCENTRATION }\end{array}$ & WASTE CONTENTS & TMU \\
\hline TRU Active & $100 \mathrm{n} \mathrm{Ci/g} \mathrm{(Pu)}$ & Lab Waste & $\pm 40 \mathrm{n} \mathrm{Ci/g}$ \\
\hline TRU Active & $10 \mathrm{n} \mathrm{Ci/g} \mathrm{(Pu)}$ & Lab Waste & $\pm 4 \mathrm{n} \mathrm{Ci/g}$ \\
\hline TRU Active & $400 \mathrm{~g}(\mathrm{Pu})$ & Moderate Absorber & $\pm 75 \mathrm{~g}$ \\
\hline TRU Passive & $10 \mathrm{~g}(\mathrm{Pu})$ & Lab Waste & $\pm 4 \mathrm{~g}$ \\
\hline
\end{tabular}

NOTE: "Moderate absorber" means a medium density $(6-121 \mathrm{~b} / \mathrm{cu} . \mathrm{ft})$ waste consisting of such things as wood, construction materials, and other relatively light weight materials but without chlorinated plastics or other neutron moderators or high atomic number materials.

I. The entire system shall be housed in a common single trailermounted enclosure shared with the NDE equipment described in Section 4.2.3, capable of providing protection for the equipment from blowing dust, snow, and water leakage. Additional audible and visual warning signals (rotating beacon type) will be added to the exterior of the trailer so that it can be plainly determined when the NDA and NDE systems are operating. The exterior components of the NDE and NDA systems must be capable of operation between exterior temperatures of freezing to $120^{\circ} \mathrm{F}$. The environment inside the trailer shall be capable of being controlled to within 30 to $50 \%$ relative humidity and between of $55^{\circ}$ to $90^{\circ} \mathrm{F}$ during equipment operations. The unit shall be designed to be rugged or easily secured for transport and shall be capable of being stored on site in the open. It must be able to accept and present 55-gallon drums or 85-galion drum overpacks at a loading and/or unloading station so that a fork lift fitted with a drum handler can be used to place or receive the drum.

J. A blue rotating beacon warning device shall be provided in the assay system room. The beacon will be activated anytime the system is in use. 


\subsubsection{CVS Equipment}

A. The Project $W-113$ CVS equipment will be similar to the CVS equipment developed for the retrieval demonstration project and other DOE sites CVS equipment except with some modifications as described in Sections 4.2.5.1 through 4.2.5.15.

B. The entire system shall be housed in a trailer-mounted enclosure capable of providing protection for the equipment from blowing dust, snow, and water leakage. The environment shall be capable of being controlled to within 30 to $50 \%$ relative humidity and between $55^{\circ}$ to $90^{\circ} \mathrm{F}$ during equipment operations. The unit shall be designed to be rugged or easily secured for transport and shall be capable of being stored on site in the open. It must be able to accept and present 55-gallon drums or 85-galion drum overpacks at a loading and/or unloading station so that a fork 1 ift fitted with a drum handler can be used to place or receive the drum.

\subsubsection{CVS Enclosure Assembly}

A. The CVS enclosure assembly shall have the following design features.

1. Material used is not likely to be damaged by a drum explosion at the worst case during the venting operation and caused the release of drum contents and personnel injury.

2. The operator's viewing window shall not only be shatterproof material but must be at least equal in strength to the materials used for the construction of the heavy-walled enclosure. Materials such as lexan and lexgard, which are used for explosive shields, can provide this strength.

3. Interior surfaces shall be coated with a high-gloss epoxy based paint that can be easily decontaminated.

B. Electrical devices located inside the CVS enclosure shall be designed and approved for installation in a Class 1, Division 2 hazardous area.

C. Provide entry and exit doors on the enclosure for a drum conveyor system that will be used to put the drum in and out of the enclosure. A forklift will be used to put the drum on the drum conveyor system.

D. Provide a drum enclosure ventilation exhaust fan installed after the HEPA filter. The stack exhaust fan blade shall be constructed of non-sparking material to minimize the potential for sparking. Radiation monitoring equipment shall be provided and designed in accordance with the ANSI N13.1 requirements.

E. Include a design provision for operating the drum venting/head gas sampling equipment with a 55-gallon drum that is already overpacked with the overpacked drum lid-off as well as without overpacks. 


\section{WHC-SD-W113-SDRD-001 REV 0}

\subsubsection{CVS Control Room}

A. The CVS control room shall be provided with:

1. Adequate ventilation to adequately dilute any internal release of flammable gases or vapor

2. A viewing window to allow the operator to view the venting operations

3. Venting, sampling and purging control panel

4. Gas sampling/analysis instrumentation system racks and work bench.

B. Process alarms shall be displayed on the CVS control panel.

C. The gas sampling/analysis instrumentation system shall be plumbed directly to the drum venting equipment to eliminate the possibility of a mix-up with previous samples.

D. Process piping entering the control room shall be provided with shutoff valves for emergency isolation.

E. Process piping within the control room shall be kept to a minimum.

F. False ceilings and floors shall not be used in the control room.

G Provide HVAC in the control room.

\subsubsection{Drum Lid Filter}

A. After the inert gas purging, a filter with the following design requirements shall be installed in the 55-gallon drum 1 id.

1. The filter will provide adsorption of volatile organic compounds and particulates but will permit the passage of hydrogen and other inorganic gases.

2. The filter design shall be a DOT approved design.

B. Filter size and material shall be coordinated with the method used for drum penetration.

C. A method of detecting alpha contamination around the base of the newly installed filter vent shall be provided.

\subsubsection{Gas Sampling Transport Lines}

A. The gas sampling transport lines shall be provided with the following.

1. Sample tap connection(s) for batch gas archive sample, flammability test and volatile organic compounds (VOC) constituent analysis. 
2. Filter(s)/differential pressure indicator(s), pressure reducing regulator(s), flow regulating valve(s) and flow monitor(s) as required.

3. Flexible stainless steel or flexible Teflon (trademark) or other highly corrosion-resistant material.

4. Electrical heat tracing and low point liquid drain(s) to avoid condensation of moisture and/or VOC.

B. Regular maintenance and inspection of the sampling lines and periodic leak tests in order to avoid significant changes in the composition of the gas sample as it passes through the sampling, cleaning and conditioning system caused by air infiltration into the lines.

C. The metal chips produced during drilling process must not block the pneumatic lines.

D. The sealing gasket must maintain a good vacuum seal without manually applying sealant on the gasket. A clean, relatively corrosion-free and flat drum (maximum of $2 \mathrm{~mm}$ deviation) surface is required for the chamber to maintain a seal on the drum penetration.

E. The flow through the sample bottles should be manually controlled with flow control valves and measured with flow indicators for a specified period of time to ensure ample gas samples have been collected. The solenoid valves shall be of the explosion-proof type. The solenoid valves shall be closed (de-energized) on loss of vacuum.

\subsubsection{Drum Vented Gas System}

A. All the drum vented gases will be monitored by an alpha CAM, a beta CAM, and a gamma detector before being discharged inside the trench enclosure building.

B. The sampling and monitoring instrumentation systems shall be designed to be placed as near as possible to the CVS enclosure's exhaust stack.

C. The CVS vented exhaust gases shall be filtered to prevent release of radioactive particulates and VOC gases to the environment. The exhaust vent shall be fitted with a HEPA filter to remove particulates and a carbon adsorber to remove gases. The HEPA filters and carbon adsorber shall meet the applicable requirements of ASME N509. Differential pressure gauges across the HEPA filter shall be provided. This filtration will remove VOC gases and particulates to regulatory levels.

D. The drum vented gas system shall:

1. Be able to function properly in the chemical environment of the exhaust 
2. Provide alarms (high radiation, instrument failure and loss of electrical power) both locally at the CVS control room and remotely in the general office building

3. Remain functional during loss of building power

4. Collect stack record air samples at an optimum flow rate of $2 \mathrm{cfm}$ for a minimum of 1 week or 168 hours runining time

5. Be provided with a flow rate meter and a flow volume totalizer installed downstream of the sample collection point of the record sampling system

6. A running time meter shall be provided for indication of accumulated stack operating time.

E. The drum vented gas sampling line shall:

1. Be as short as possible in length between the sampling probe and the sample filter holder

2. Minimize horizontally run line

3. The number and angle of bends should be minimized

4. Have bends with a radius of at least ten (10) times the inside diameter of the sampling line

5. Minimize the use of piping or tubing fittings between the sample probe and the sample filter holder

6. Use thermostatically controlled electrical heat tracing of the sampling line where condensation is a potential problem.

F. The sample head and probe shall be:

1. Installed facing upstream into the direction of flow

2. Detachable for ease of maintenance and decontamination

3. Provided with a flow rate indicator and regulator downstream of the sample filter holder

4. Provided with a compression ring designed to press the perimeter of the filter against the backing support of the sample filter holder to ensure an airtight seal

5. At least 5 duct diameters downstream and 2 duct diameters upstream of any major flow disturbance.

G. The venting enclosure exhaust fan shall be electrically interlocked with the record sampling line vacuum pump, such that it will prevent a sample from being taken when the exhaust fan is shutdown. 
H. Sufficient vacuum pump capacity shall be provided to maintain a minimum flow of $2 \mathrm{cfm}$ through the record sample filter. A line loss study will have to be performed to determine sample line size and optimum flow rate for a semi-isokinetic sample.

I. The record sampler collects representative stack exhaust particulates on a filter paper. This filter is to be periodicaliy removed for laboratory type analysis on the collected particulates, measured for concentration of the various contaminants. The record sample filter paper will be sent to an onsite WHC laboratory for the required analysis.

\subsubsection{Inert Gas Purging System}

A. If the drum headspace gas mixtures is in the flammable or explosive range, the drum will be purged with inert gas until the gas mixtures is no longer flammable based on the flammability test.

B. The flow rate of purge gas shall be sufficient to ensure adequate mixing so that release of a flammable gas or vapor is limited.

C. Precautions shall be taken to protect the drum from excessive pressure of the purge supply.

D. The drum piercing containment enclosure shall be purged during the time the 55-gallon drum 1 id is to be penetrated. Extreme caution should be taken in purging the drum. If the headspace gases have powder or aerosol contamination, this should be captured (e.g., with a HEPA filter) by the purge system, rather than vented to the atmosphere freely. Otherwise, any workers at the venting station would probably require supplied air.

E. Four nitrogen cylinders are to be manifolded for a quick manual switchover from the other nitrogen bottle that becomes empty during the inert gas purging.

\subsubsection{Gas Mixtures Flammability Testing}

A. ALTERNATIVE \# 1 : If the gas flammability test equipment is directly plumbed in, a flashback arrestor constructed to perform the following safety function shall be installed between the sampling line and the gas mixtures flammability test equipment.

1. Stop and extinguish a flashback with a sintered high-flow filter.

2. Stop the backflow of gases with a non-return valve.

3. Prevent the further supply of gas following a flashback with a pressure activated positive valve lock. 
B. ALTERNATIVE \#2: If the gas mixtures flammability test equipment is not plumbed in to the gas sampling line, an alternative safer method will be to get an extra gas grab sample for the gas mixtures flammability. The gas mixtures flammability testing will be done with the gas flammability test equipment not plumbed in to the gas sampling line.

C. Adequate shielding around the gas mixtures flammability test equipment shall be provided to prevent personnel injury in the event of energetic explosions that might occur.

\subsubsection{Hydrogen Gas Monitoring System}

A. It shall monitor specifically for the flammable gas concentrations of hydrogen ( $1 \% \mathrm{LEL}$ ) in the drum headspace atmosphere and not affected by the presence (but not limited to) unknown quantities of air, oxides of nitrogen, water vapor, carbon dioxide, carbon monoxide, and other gaseous constituents.

B. The hydrogen gas monitoring sensor shall be intrinsically safe and specifically design for hydrogen gas. The hydrogen gas monitoring system shall be suitable and classified for use in potentially explosive environments.

C. Automatic temperature compensation, pressure compensation, insensitivity to the sample flow rate shall be provided to make the analys is independent of sample conditions.

D. It shall have provisions for:

1. A 4-20 mA dc signal interface to either a local or remote data acquisition system

2. A local readout display and a local strip chart recorder as a backup recording system

3. Automatic temperature, pressure compensation and insensitivity to flow rate to make analysis independent of sample conditions

4. An accuracy equal to or better than the absolute value of \pm $0.25 \%$ hydrogen in the $0-5 \%$ LEL hydrogen range

5. A repeatability equal to or better than $\pm 1.0 \%$ of full scale

6. A minimum detection range capability of 0 to $5 \%$ LEL hydrogen

7. A temperature stability better than or equal $\pm 0.005 \%$ hydrogen per degree $F$.

E. The instrument output shall be capable of reaching $90 \%$ of the final value in two minutes or less after applying a step increase or decrease of at least $25 \%$, but not to exceed $100 \%$ of the instrument full scale. 


\subsubsection{Butane Gas Monitoring System}

A. ALTERNATIVE \#1: The butane gas monitoring system will have the same design requirements as the hydrogen monitoring system described in Section 4.2.5.8, except it will monitor specifically for the flammable gas concentrations of butane $(0.5 \% \mathrm{LEL})$.

B. ALTERNATIVE \#2: Butane gas will be monitored by the vOC gas analyzer to be provided per Section 4.2.5.12.

\subsubsection{Methane Gas Monitoring System}

A. ALTERNATIVE \#1: The methane gas monitoring system will have the same design requirements as the hydrogen gas monitoring system described in Section 4.2.5.8, except it will monitor specifically for the flammable gas concentrations of methane $(1.25 \% \mathrm{LEL})$.

B. ALTERNATIVE \#2: Methane gas will be monitored by the VOC gas analyzer to be provided per Section 4.2.5.12.

\subsubsection{VOC Gas Continuous Monitor}

A. ALTERNATIVE \#1: The on-line VOC gases continuous monitoring instrumentation to be used shall have provisions for:

1. Communication interface to either a local or remote data acquisition system

2. A local readout display or a local strip chart recorder as a backup recording system.

B. ALTERNATIVE \#1: The on-line VOC gases continuous monitoring instrumentation will be provided in the VOC gas analyzer provided in Section 4.2.5.12.

\subsubsection{VOC Gas Analyzer}

A. ALTERNATIVE \#1: The on-1ine VOC gases analyzer (gas chromatograph/mass spectrometer) to be used for the VOC constituent gas analysis shall have provisions for:

1. Communication interface to either a local or remote data acquisition system

2. Capability to store and print gas analysis report.

B. ALTERNATIVE \#2: The on-line VOC gases analyzer (Fourier Transform Infrared Spectrometer (FTIR)) to be used instead shall have the same provisions. 


\subsubsection{CVS Workplace Monitoring}

A portable gas leakage detector that will be required per OSHA 29 CFR 1910.120 to monitor the workplace around the drum venting heavy-walled enclosure for workers health and safety, shall be approved for Class I, Division 2 usage.

\subsubsection{CVS Equipment Bonding/Grounding}

Bonding or grounding wires with either a C-clamp or electrical terminal lugs on both ends of the bonding/grounding wires should be used to connect metal parts required to be electrically connected to assure electrical conductivity between the parts and connect the drum directly to ground or through an intermediate conductor.

\subsubsection{Miscellaneous Requirements}

A. The programmable logic controller (PLC) to be used shall have communication interfaces capability to the Project W-113 DMS and incorporate the following process control logic.

1. Automatic insertion of the drum lid filter after drum inert gas purging.

2. Automatic start of the enclosure exhaust fan as soon as the enclosure's drum entry and exit doors are closed.

3. Automatic evacuation of the gas sampling line before the drilling and venting of the next drum in order to get a truly representative gas sample for each drum.

4. Alarm and abnormal warning pilot light(s) activated through the programmable controller shall be provided on the CVS graphic display panel. NOTE: Example of some process conditions that may be considered for alarm indications are loss of vacuum and venting enclosure's exhaust fan not operational.

5. During the sequence of operations, additional flashing lights are to be used as visual aids to the operator that some other operator interface action is needed for the next automatic sequence to occur. NOTE: Most of these actions refer to subsystem equipment that are not included in the programmable controller logic, but are hard-wired to the electrical power source, such as the system vacuum pump and the air compressor.

B. Hard-wired electrical interlocks that will prevent drilling and venting if the following conditions exists.

1. Drum enclosure entry and exit doors are open.

2. Drum is not properly positioned or aligned for drilling.

3. Enclosure exhaust fan is not operational. 


\section{WHC-SD-W113-SDRD-001 REV 0}

4. Trench enclosure building's portable exhausters are not operational.

5. Drum lid is not properly clamped and sealed.

6. Emergency stop button is activated by the process operator.

7. Mechanical problems during drilling (such as a broken bit).

C. Electrical devices such as the pushbuttons, selector switches, and indication lights shall be oil-tight and of the industrial grade type.

D. An instrument air dryer shall be provided to process the compressed air beyond the aftercooler and receiver to further reduce moisture content. Provision for draining and disposal of the condensate from the air receiver and the in-line filter separator should be included.

E. The vacuum pump capacity to include its use as the vacuum source for the stack exhaust gases radionuclide monitoring system. NOTE: A separate vacuum pump which is a component part of the continuous gas monitor will be used for drum head gas sampling and VOC monitoring.

F. The sealing and clamping cylinders bore sizes shall be selected for the maximum force expected for drum explosion. Solenoid valves shall be of the explosion-proof type.

\subsubsection{Man-lift}

The following design requirements shall be used in the procurement specification for an electrically-powered aerial work platform (man-lift) equipment.

A. It must have at least a 550-1b lifting capacity, with shielding provisions and a working height of at least $6.7 \mathrm{~m}(22 \mathrm{ft})$.

B. The work platform to be provided shall be sized for at least 2 people, one of which would be an HPT.

C. The controls for the lift shall be operated from the manlift basket.

D. It must be driveable at full height.

E. Overhead protective coverings shall be provided on the top of the platform. 


\subsection{REFERENCES}

ANSI/NFPA, 1992, Powered Industrial Trucks Including Type Designations, Areas of Use, Maintenance, and Operation, NFPA 505, American National Standard Institute/National Fire Protection Association, New York, New York.

Boothe, G. F., 1993, Radiological and Chemical Source Terms for Solid Waste Operations Complex, WHC-SD-W306-TI-001, REV 0, Westinghouse Hanford Company, Richland, Washington.

DOE, 1992, Environmental Protection, Safety, and Health Protection Standards, DOE Order 5480.4, U.S. Department of Energy, Washington, D.C.

DOE, 1989, General Design Criteria, DOE Order 6430.1A, U.S. Department of Energy, Washington, D.C.

DOE-RL, 1992, Hanford Site Hoisting and Rigging Manual, DOE-RL-92-36, U.S. Department of Energy, Richland Operations Office, Richland, Washington.

DOE-RLIP, 1992, Environmental Protection, Safety, and Health Protection Standards for RL, DOE-RLIP Order 5480.4C, U.S. Department of Energy, Washington, D.C.

Johnson, D. M., 1993, Solid Waste Retrieval Facility Phase 1, Project W-113, Functional Design Criteria, WHC-SD-W113-FDC-001, Rev 2, Westinghouse Hanford Company, Richland, Washington.

McCormick, W. A., 1993, Packaging Design Criteria, Project W-113 Box Packaging, WHC-SD-TP-PDC-014, REV 0, Westinghouse Hanford Company, Richland, Washington.

NFPA, 1993, National Electrical Code, NFPA 70, National Fire Protection Association, Boston, Massachusetts.

NFPA, 1991, Life Safety Code, NFPA 101, National Fire Protection Association, Boston, Massachusetts.

NFPA, 1993, Purged and Pressurized Enclosures for Electrical Equipment, NFPA 496, National Fire Protection Association, Boston, Massachusetts.

Ocampo, V. P., 1993, Project W-113 Drum Venting and Head Gas Sampling System, WHC-SD-W113-ES-003, REV 0, Westinghouse Hanford Company, Richland, Washington.

OSHA, 1993, Powered Industrial Trucks, 29 CFR 1910.178, Occupational Safety and Health Administration, Washington, D.C.

Smith, K. E., 1994, Solid Waste Retrieval Facility Phase 1, Project W-113, Advanced Conceptual Design Report, WHC-SD-W113-ACDR-001, Rev.0, Westinghouse Hanford Company, Richland, Washington. 